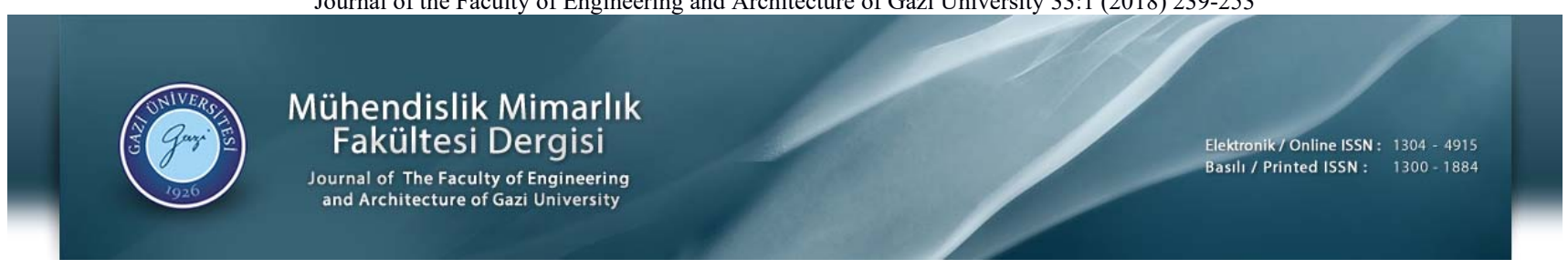

\title{
Yapay arı koloni algoritması kullanılarak betonarme istinat duvarlarının optimum maliyet tasarımını etkileyen parametrelerin incelenmesi
}

Uğur Dağdeviren*(D), Burak Kaymak (DD

Dumlupınar Üniversitesi, Mühendislik Fakültesi, İnşaat Mühendisliği Bölümü, Kütahya, 43100, Türkiye

Ö N E Ç I K A N L A R

- Minimum maliyetli betonarme istinat duvarı tasarımı

- Bazı tasarım parametrelerinin minimum maliyet üzerindeki etkilerinin araştırılması

- Duvar maliyetini etkileyen öncelikli parametrelerin değerlendirilmesi

Makale Bilgileri

Geliṣ: 24.10.2016

Kabul: 22.05.2017

DOI:

10.17341/gazimmfd.406796

Anahtar Kelimeler:

Optimum maliyet tasarımı, betonarme istinat duvarı, yapay arı koloni algoritması, parametre analizi

\section{ÖZET}

Uygulamada yaygın kullanım alanı bulunan betonarme istinat duvarlarının analiz ve tasarımı, geoteknik mühendisliği ve yapı mühendisliğinin önemli problemlerindendir. Betonarme istinat duvarlarının stabilitesi değerlendirilirken, iç ve dış stabiliteye dayalı çok sayıda göçme modunun birlikte düşünülmesi gerekmektedir. Minimum maliyetli betonarme istinat duvarı tasarımı; dolgu özellikleri, temel zemini özellikleri ve duvar özellikleri gibi çok sayıda parametreden etkilenmektedir. Bu çalışmada, sağlam temel zeminine oturan istinat duvarlarının maliyeti üzerinde farklı dolgu içsel sürtünme açıları, sürşarj yükleri, duvar yükseklikleri ve duvarın ön kısmında oluşacak pasif dirençlerin etkilerinin ayrı ayrı ele alındığı toplam 500 optimizasyon problemi tanımlanmıştır. Bu problemlerin çözümü için, yapay arı koloni (ABC) algoritması kullanılarak minimum maliyetli istinat duvarı tasarımları elde edilmiştir. Çalışma sonucunda, her bir metrelik duvar yüksekliği artışının duvar maliyetini \%31 ile \%46 arasında arttırdığı tespit edilmiştir. Her 10 kPa'lık sürşarj yükü artışı maliyeti ortalama \%12,7 arttırırken, dolgunun içsel sürtünme açısındaki artış duvar maliyetini \%13,4 ile \%18,9 arasında azaltmaktadır. Ayrıca, çalışma sonucunda, sağlam temel zemini koşullarındaki betonarme istinat duvarlarında, duvar önündeki pasif direncin duvar maliyeti üzerinde etkisinin olmadığı anlaşılmıștır.

\section{Investigation of parameters affecting optimum cost design of reinforced concrete retaining walls using artificial bee colony algorithm}

\section{H I G H L I G H T S}

- Design of the reinforced concrete retaining wall with minimum cost

- Investigation of the effects of some design parameters on minimum cost

- Evaluation of the prior parameters affecting the cost of wall

Article Info

Received: 24.10 .2016

Accepted: 22.05 .2017

DOI:

10.17341/gazimmfd.406796

Keywords:

Optimum cost design, reinforced concrete retaining wall,

artificial bee colony

algorithm,

parameter analysis

\section{ABSTRACT}

The analysis and design of the reinforced concrete retaining walls (RCRWs) that are commonly used in practice are one of the important problems in geotechnical engineering and structural engineering. As the overall stability of RCRWs is evaluated, lots of different failure modes based on external and internal stability must be considered together. The design of RCRW with minimum cost is affected by many parameters such as backfill, foundation soil and wall properties. In this paper, a total of 500 optimization problems were separately defined to investigate the effects of different internal friction angles of backfill, surcharge loads, heights of the wall and passive resistances at the front of the wall on the cost of the retaining walls resting on strong foundation soil. For solving these problems, minimum cost designs of RCRW were obtained by using the artificial bee colony $(\mathrm{ABC})$ algorithm. As a result of the study, it was determined that the cost of the wall increased between $31 \%$ and $46 \%$ for each one-meter increase in height of the wall. As the cost rises by average $12.7 \%$ for each $10 \mathrm{kPa}$ increase in surcharge load, the increase in the internal friction angle of backfill decreases the cost of the wall between $13.4 \%$ and $18.9 \%$. In addition, the results of the study reveal that the passive resistance at the front of the wall does not affect the cost of the RCRW at the strong foundation soil conditions. 


\section{GIRISS (INTRODUCTION)}

Dayanma yapıları, yamaçlar ve şevlerde farklı iki zemin kotu arasındaki zemin stabilitesini sağlayabilmek için inşa edilen ve inşaat mühendisliği uygulamalarında sıklıkla kullanılan yapılardır. Dayanma yapılarının en yaygın türlerinden olan betonarme istinat duvarlarının analiz ve tasarımı sırasında birçok farklı göçme modunun birlikte düşünülmesi gerekmektedir. Tasarlanan betonarme istinat duvarının bir bütün olarak devrilme, kayma ve temel zemini açısından stabil olmasının yanı sira duvarın gövde, topuk ve burun kısmında oluşacak olan eğilme momentleri ve kesme kuvvetleri de emniyetli olarak karşılanmalıdır. Betonarme istinat duvarlarının klasik tasarım prosedüründe, öncelikle kullanılacak olan dolgu ve duvar malzemelerinin özellikleri ile duvar kesiti boyutları gibi tasarım değişkenleri mühendislik deneyimlerine dayalı olarak seçilmektedir. Daha sonra, yanal toprak basincı teorisine göre duvara etkiyen gerilmeler ve kuvvetler hesaplanmakta, gerekli analizler neticesinde tasarım kriterlerinin sağlanıp sağlanmadığı kontrol edilmektedir. Eğer seçilen tasarım değişkenleri gerekli şartları sağlamıyorsa veya oldukça yüksek maliyete sebep oluyorsa, duvarın tasarım değişkenleri yeniden belirlenmekte ve kontrol işlemleri tekrarlanmaktadır. Tasarım sinırlamalarına göre, en ekonomik duvar tasarımı elde edilene kadar, bu süreç deneme yanılma şeklinde devam etmektedir. Bu genel yaklaşımla optimum tasarımın sağlanması oldukça zor ve zaman alıcı olduğu için, betonarme istinat duvarları tasarımının bir optimizasyon problemi olarak ele alınması zorunlu hale gelmektedir. Optimizasyon teknikleri matematiksel ve sezgisel metotlar olmak üzere iki ana sınıfta toplanabilir. Günümüzde, özellikle kullanım kolaylığ optimum değere yakınsama hızı, optimum değeri belirleyebilmek ve birçok mühendislik probleminin karakterinde olan doğrusal olmama durumlarında dahi uygulanabilirliği gibi önemli avantajlara sahip olmasından dolay1, sezgisel metotlar mühendislik problemlerinde oldukça yaygın olarak kullanılmaktadır.

Karaboğa [1] tarafından geliştirilen ve sezgisel metotlardan birisi olan yapay ar1 koloni algoritması (Artificial Bee Colony, ABC) diğer sezgisel yöntemlere kıyasla, basitlik, esneklik, kararlılık, daha az algoritma parametresine ihtiyaç duyması, diğer optimizasyon algoritmaları ile kolay melezlenebilmesi ve algoritmanın performansının yüksek olması gibi çok sayıda avantaja sahiptir [2, 3]. ABC algoritmasının çok boyutlu ve çok modlu nümerik problemleri [2], otomatik kümeleme problemi [4], çevresel ekonomik güç dağıtımı problemi [5], kafes yapı tasarımı [6] ve kablosuz sensör ağları [7] gibi birçok farklı alanlarda başarılı bir şekilde uygulanmış oluşu, algoritmanın bu çalışma için tercih edilmesinde belirleyici olmuştur. Literatürde, optimum maliyetli veya optimum ağırlıklı betonarme istinat duvarları tasarımı için gerçekleştirilmiş birçok çalışma bulunmaktadır. Konunun öncülerinden olan Saribas ve Erbatur [8] betonarme istinat duvarlarının optimum ağırlık ve optimum maliyet tasarımını nonlineer programlama problemi olarak ele almışlardır. Son yıllarda yapılan çalışmalar ise, betonarme istinat duvarlarının optimum tasarımında sezgisel yöntemlerin kullanılabilirliği üzerine yoğunlaşmıştır. Ceranic vd. [9] minimum maliyetli betonarme istinat duvarı tasarımı için tavlama benzetimi algoritmasını (Simulated Annealing) kullanmıştır. Babu ve Basha [10] hedef güvenilirlik yaklaşımını (Target Reliability Approach) kullanarak betonarme istinat duvarının güvenilirlik tabanlı tasarım optimizasyonu için bir yaklaşım tanımlamışlardır. Yepes vd. [11] tavlama benzetimi algoritmasinı kullanarak optimum maliyetli istinat duvarı tasarımını etkileyen ana faktörlerin etkilerini araştıran parametrik bir çalışma yapmıştır. Betonarme istinat duvarlarının optimum tasarımı için Ahmadi-Nedushan ve Varaee [12] parçacık sürü optimizasyonunu (Particle Swarm Optimization), Ghazavi ve Bonab [13] karınca koloni optimizasyonunu (Ant Colony Optimization), Ghazavi ve Salavati [14] bakteri yiyecek arama optimizasyonunu (Bacterial Foraging Optimization) kullanmışlardır. Kaveh ve çalışma grubu, optimum istinat duvarı tasarımı için armoni arama algoritması (Harmony Search), yüklü sistem arama algoritması (Charged System Search) [15, 16] ve 1şın optimizasyonu (Ray Optimization) yöntemlerini önermişlerdir [17]. Camp ve Akin [18] büyük patlama büyük çöküş optimizasyonunu (Big bang-big crunch optimization), Akin ve Aydogdu [19] ile Sheikholeslami vd. [20] ise adaptif ve iyileștirilmiş ateș böceği algoritmalarını (Firefly Algorithm) düşük maliyetli ve düşük ağırlıklı istinat duvarı tasarımı için uygulamışlardır. Pei ve Xia [21] aynı problem için genetik algoritma (Genetic Algorithm), parçacık sürü optimizasyonu ve tavlama benzetimi algoritmasını içeren bazı sezgisel yöntemlerin kullanılabilirliğini incelemişlerdir. Khajehzadeh vd. [22] karşıt temelli öğrenmeye dayalı kütle çekimsel arama algoritmasının (Gravitational Search Algorithm) yeni bir versiyonunu istinat duvarlarının optimum tasarımı için uygulamışlardır.

Ancak, literatürdeki bu çalışmalar genellikle farklı optimizasyon teknikleri ile betonarme istinat duvarlarının tasarımı üzerinde yoğunlaşmakta ve sadece birkaç örnek üzerinde ele alınan algoritmanın performansını ve kullanılabilirliğini ölçmektedirler. Bu çalışmada ise sağlam temel zeminine oturan istinat duvarlarının maliyeti üzerinde kullanılan dolgu malzemesi için farklı içsel sürtünme açılarının, sürşarj yüklerinin, duvar yüksekliklerinin ve duvarın ön kısmında oluşacak pasif direncin etkileri ele alınmıştır. Bu amaç doğrultusunda, tanımlanan toplam 500 optimizasyon problemi yapay ar1 koloni algoritmas1 kullanılarak analiz edilmiş ve ele alınan parametrelerin optimum maliyet üzerindeki etkileri tartışılmıştır. Makalenin 2. Bölümünde betonarme istinat duvarlarının tasarım detayları verilmiştir. Bölüm 3'de yapay arı koloni algoritmasının uygulama esasları ele alınmıştır. Betonarme istinat duvarı optimizasyon problemi Bölüm 4'de tanımlanmış olup, gerçekleştirilen analizlere ait sonuçlar Bölüm 5'de tartışılmıştır. Makalenin son bölümünde ise çalışmadan elde edilen önemli bulgular sunulmuştur. 


\section{BETONARME ISTINAT DUVARLARININ TASARIMI (DESIGN OF THE REINFORCED CONCRETE RETAINING WALLS)}

Tipik gösterimi Şekil 1'de verilen bir betonarme istinat duvarının tasarımında ilk olarak duvara etki eden düşey ve yatay kuvvetlerin belirlenmesi gerekmektedir. İstinat duvarına etki eden düşey kuvvetler: 1) duvarın gövdesinin ve temelinin ağırlığ $\left.\left(\mathrm{W}_{\mathrm{w}}\right), 2\right)$ duvarın topuk kısmı üzerinde yer alan dolgu zemininin ağırlığı $\left.\left(\mathrm{W}_{\mathrm{s}}\right), 3\right)$ burun kısmındaki zeminin ağırlığı ve 4) topuk kısmı üzerindeki sürşarj (q) yüküdür. Analizlerde emniyetli tarafta kalmak için genellikle 3. ve 4. sıradaki kuvvetler ihmal edilmektedir. İstinat duvarına etki eden yatay kuvvetler ise, dolgu zemini ve tabii zeminden kaynaklanan, sirasiyla, aktif $\left(\mathrm{P}_{\mathrm{a}}\right)$ ve pasif $\left(\mathrm{P}_{\mathrm{p}}\right)$ toprak itkileri ile sürşarj yükünden kaynaklanan yanal kuvvetlerdir $\left(\mathrm{P}_{\mathrm{q}}\right)$. Bu kuvvetler duvar ile zemin arasında sürtünmenin olmadığı ve duvar arkasındaki zemin yüzeyinin eğimsiz olduğu durumlarda, Rankine' in yanal toprak basinc1 teorisine dayalı olarak Eş. 1'de verilen aktif toprak basinc1 katsayısı $\left(\mathrm{K}_{\mathrm{a}}\right)$ kullanılarak hesaplanabilir.

$$
K_{a}=\tan ^{2}\left(45-\frac{\phi_{1}}{2}\right)
$$

Burada, $\phi_{1}$, derece cinsinden, dolgu zemininin içsel sürtünme açısı değeridir.

Betonarme istinat duvarlarının tasarımında iki temel analiz esas alınmaktadır. Bunlar: 1) dış stabilite analizleri (geoteknik tasarım) ve 2) iç stabilite analizleridir (yapısal tasarım). Dış stabilite analizlerinde, istinat duvarı bir bütün olarak ele alınmakta ve duvarın devrilmeye, kaymaya, temel zemininin ise taşıma gücü ve eksantrisiteye karşı güvenliği kontrol edilmektedir. İç stabilite analizlerinde ise duvar gövdesinin ve temelinin kesme ve eğilme açısından uygunluğu incelenmektedir. Bir betonarme istinat duvarının devrilmeye karşı güvenliği belirlenirken, duvarın burun noktası (Şekil 1.a'da gösterilen O noktas1) etrafında devrilmeye karşı direnen toplam momentler $\left(\Sigma \mathrm{M}_{\mathrm{R}}\right)$, duvarı devirmeye çalışan kuvvetlerin toplam momenti $\left(\Sigma \mathrm{M}_{\mathrm{O}}\right)$ ile kıyaslanmaktadır. Eş. 2'de tanımlanan devrilmeye karşı güvenlik sayısının, genellikle, granüler zeminler için 1,5, kohezyonlu zeminler için ise 2,0'den büyük olması istenmektedir [23].

$$
F S_{(\text {devrilme })}=\frac{\sum M_{R}}{\sum M_{O}} \geq F S_{(d, \text { min })}
$$

Kayma yenilmesine karşı güvenlik sayısı ise Eş. 3'de ifade edilen kaymaya karşı direnen kuvvetlerin toplamının $\left(\Sigma F_{R}\right)$, kaydırıcı kuvvetlerin toplamına $\left(\Sigma \mathrm{F}_{\mathrm{S}}\right)$ oranı olarak Eş. 4'de tanımlanmaktadır. Dolgu zemini olarak kum, çakıl ve kayanın kullanıldığ 1 duvarlar için kaymaya karşı minimum güvenlik sayısı $\left(\mathrm{FS}_{(\mathrm{k}, \mathrm{min})}\right) 1,5$, kil ya da killi siltli dolgular için ise en az 2,0 olarak seçilmektedir [23, 24]. Uygulamada ise dolgu malzemesi olarak granüler zeminler kullanıldığı için kaymaya karşı güvenlik sayısı genellikle 1,5 veya daha büyük bir değer olarak alınmaktadır.

$$
\begin{aligned}
& \Sigma F_{R}=\alpha \cdot P_{p}+\Sigma V \cdot \tan \left(k_{1} \cdot \phi_{2}\right)+B \cdot\left(k_{2} \cdot c_{2}\right) \\
& F S_{(\text {kayma })}=\frac{\sum F_{R}}{\sum F_{S}} \geq F S_{(k, \text { min })}
\end{aligned}
$$

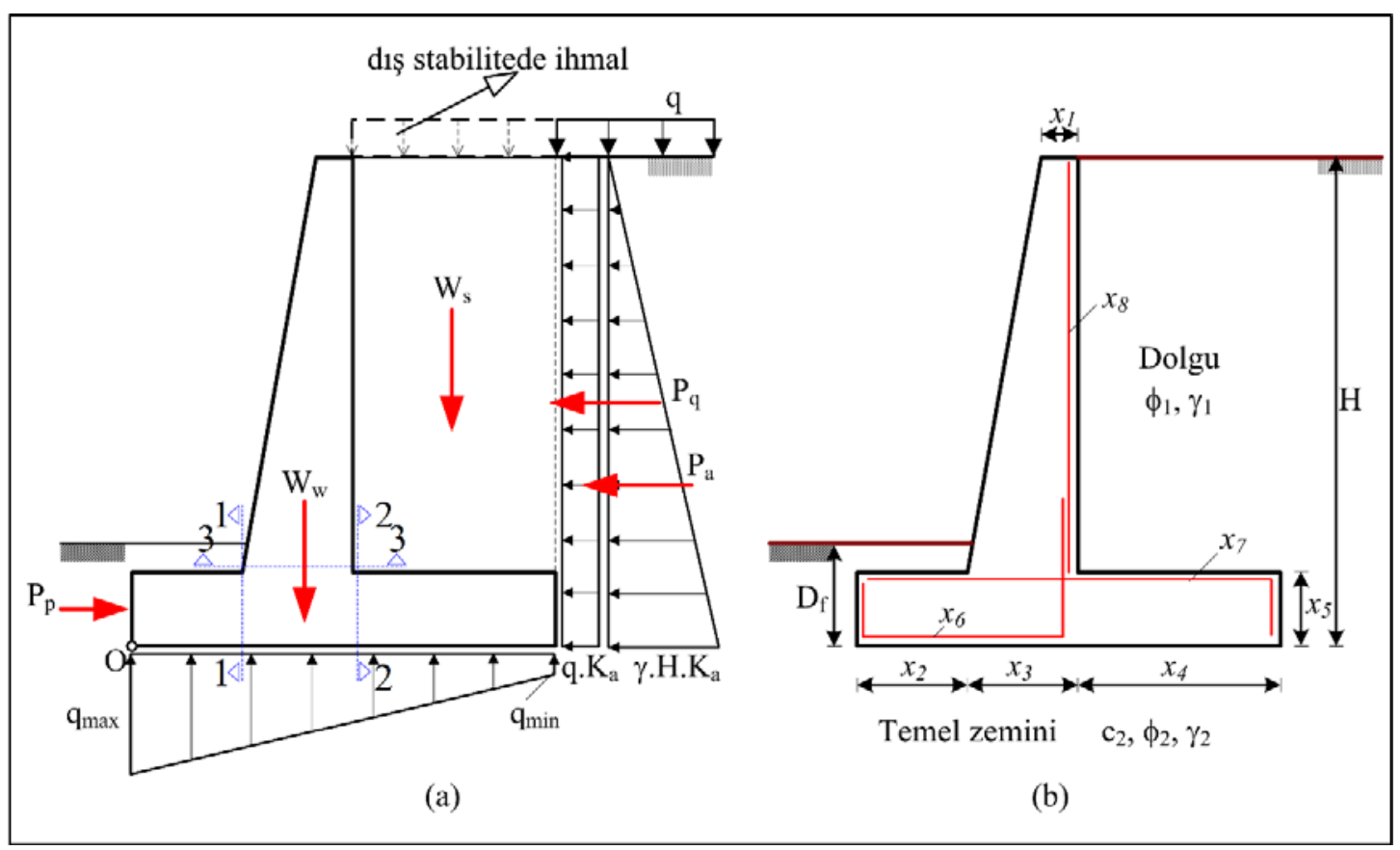

Şekil 1. a) Betonarme istinat duvarına etkiyen tipik kuvvetler b) tasarım değişkenleri (a) Typical forces acting on a reinforced concrete retaining wall b) design variables) 
Burada; $(\Sigma \mathrm{V})$, temel zeminine aktarılan toplam düşey yük; $\mathrm{B}$, temel genişliği; $\mathrm{k}_{1}$ ve $\mathrm{k}_{2}$, temel zemininin içsel sürtünme açısı $\left(\phi_{2}\right)$ ve kohezyon $\left(c_{2}\right)$ değerleri için azaltma faktörleri olup, $1 / 2-2 / 3$ aralığında seçilmektedir. $\mathrm{P}_{\mathrm{p}}$ ise pasif toprak itkisi olup, Eş. 5'den hesaplanmaktadır. Gerçek arazi koşullarında, duvar ön kısmında yer alan zeminin aşınma, taşınma gibi çevresel etkilere maruz kalması veya yeteri kadar yanal hareketin gerçekleşmemesi nedeniyle, pasif durum her zaman tam olarak oluşmayabilmektedir. Bu nedenle, bu çalışmada pasif direncin etkisinin dikkate alınma ölçüsünü hesaba katmak için pasif direnç etki katsayısı $(\alpha)$ tanımlanmıştır. Pasif direncin ihmali için $\alpha=0$ iken, pasif direncin tam olarak oluşması durumunda $\alpha=1$ olacaktır.

$P_{p}=\frac{1}{2} K_{p} \cdot \gamma_{2} \cdot D_{f}^{2}+2 c_{2} \sqrt{K_{p}} D_{f}$

$\mathrm{K}_{\mathrm{p}}$, Rankine pasif toprak basıncı katsayısıdır ve Eş. 6 ile hesaplanabilir.

$K_{p}=\tan ^{2}\left(45+\frac{\phi_{2}}{2}\right)$

İstinat duvarına etki eden düşey gerilmeler, duvar temeli aracılığıyla zemine aktarılacağı için, temel zemininin bu yükleri emniyetli olarak taşıyabilmesi gerekmektedir. Eksantrisiteden (e) dolayı temel altındaki maksimum ve minimum taban basınçları sırasıyla temelin burun ve topuk kısmında oluşacak olup taban basıncının Şekil 1.a'da görüldüğü gibi lineer olarak değiştiği kabul edilebilir. Temel zemininin nihai taşıma kapasitesi ( $q_{\text {ult }}$ ) [25] belirli bir güvenlik sayısı ile Eş. 8'den hesaplanan maksimum taban basıncını ( $\left.\mathrm{q}_{\max }\right)$ karşılayabilecek büyüklükte olmalıdır. Taşıma gücü yenilmesine karşı güvenlik sayısı Eş. 7'de tanımlanmış olup, minimum güvenlik sayısı $\left(\mathrm{FS}_{(\mathrm{t}, \mathrm{min})}\right)$ genellikle 3 olarak alınmaktadır [24].

$$
\begin{aligned}
& F S_{(\text {tasima })}=\frac{q_{u l t}}{q_{\max }} \geq F S_{(t, \min )} \\
& q_{\max }=\frac{\Sigma V}{B \times 1}\left(1+\frac{6 e}{B}\right) \\
& e=\frac{B}{2}-\frac{\Sigma M_{R}-\Sigma M_{O}}{\Sigma V}
\end{aligned}
$$

Eş. 9' da tanımlanan eksantrisite değeri, e > B/6 olduğunda, temel tabanı altındaki minimum taban basıncı $\left(\mathrm{q}_{\mathrm{min}}\right)$ negatif değer alacaktır. $\mathrm{Bu}$ durum, temel altında çekme gerilmelerinin oluşacağ çekme gerilmesi alamayacak olmasından dolayı istinat duvarının temeli ile zemin arasında bir ayrılma oluşacaktır. $\mathrm{Bu}$ yüzden, istinat duvarı tasarımında temel altındaki minimum taban basıncinın sıfirdan büyük olması gerekmektedir. Bu koşul, Eş. 10 ile ifade edilebilir.

$$
F S_{(\text {cekme })}=\frac{B / 6}{e} \geq 1
$$

Betonarme istinat duvarları için iç stabilite analizleri ise genellikle duvar gövdesi, temelin burun ve topuk kısımları olmak üzere 3 kritik kesit üzerinde uygulanmaktadır. Şekil 1.a' da gösterilen bu kritik kesitlere (1-1, 2-2 ve 3-3) etki eden gerilme dağılımları ise Şekil 2'de verilmiştir. Gövde, burun ve topuk elemanları, bir ucu ankastre kiriş olarak modellenmekte ve kesitin eğilme ve kesme gereksinimlerini sağlayacak şekilde uygun olarak boyutlandırılmalıdır. $\mathrm{Bu}$ kesitlerin moment $\left(\mathrm{M}_{\mathrm{r}}\right)$ ve kesme $\left(\mathrm{V}_{\mathrm{r}}\right)$ kapasiteleri, etki eden tasarım momenti $\left(\mathrm{M}_{\mathrm{d}}\right)$ ve tasarım kesme kuvvetinden $\left(\mathrm{V}_{\mathrm{d}}\right)$ büyük olmak durumundadır. Tasarım yükü hesaplamalarında, TS 500/2000'de belirtilen yük faktörleri, ölü yük $(G)$ için 1,4 , hareketli yük $(Q)$ için 1,6 , yatay toprak yükü $(H)$ için 1,6 olarak tanımlanmakta [26], betonarme

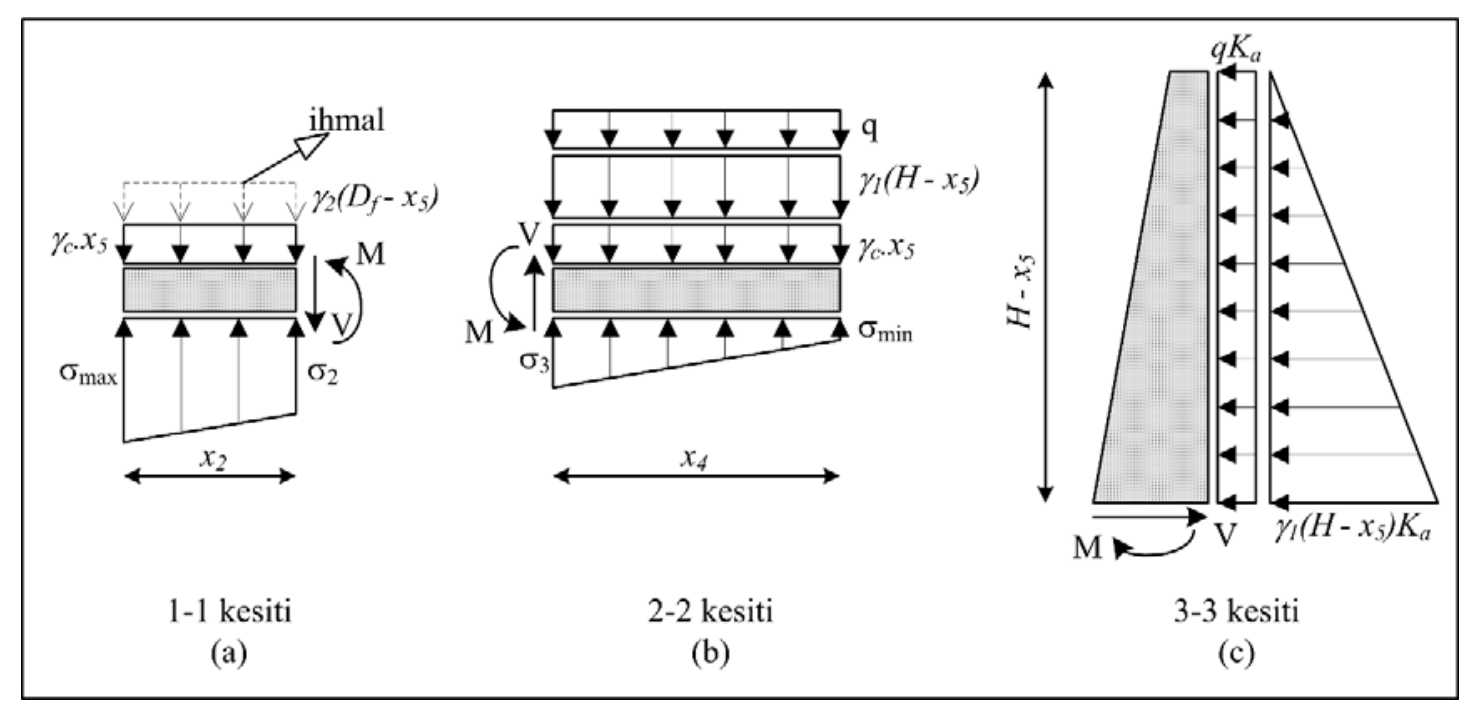

Şekil 2. a) Burun b) topuk c) gövde için kritik kesitlere etki eden gerilme dağılımları (Stress distributions acting on critical sections for a) toe b) heel c) stem) 
duvar gövdesi ve temeli için moment ve kesme kapasitesi ise Eş. 11 ve 12 'den elde edilmektedir.

$$
M_{r}=A_{s} \cdot f_{y d} \cdot\left(d-\frac{a}{2}\right) \geq M_{d}
$$

$V_{r}=0,65 \cdot f_{c t d} \cdot b_{w} \cdot d \geq V_{d}$

Burada; $f_{y d}$, çelik için tasarım akma dayanımı; $f_{c d}$ ve $f_{c t d}$, beton için sırasıyla tasarım basınç ve çekme dayanımları; $A_{s}$, donatı alanı; $b_{\mathrm{w}}$ ve d, sırasıyla, kesit genişliği ve kesit faydalı yüksekliğidir. a ise basınç bloğunun derinliği olup Eş. 13'de tanımlanmıştır.

$$
a=\frac{A_{s} \cdot f_{y d}}{0,85 f_{c d} \cdot b_{w}}
$$

İç stabilite analizleri sonunda istinat duvarının her kesitinde seçilen donatı oranlarının, ayrıca, maksimum ve minimum donatı oranları arasında kalması gerekmektedir. TS500/2000'de minimum ve maksimum donatı oranları Eş. 14 ve Eş. 15 ile tanımlanmıştır [26]. Burada, $\mathrm{k}_{1}$, betonun dayanımına bağlı bir katsayıdır.

$$
\begin{aligned}
& \rho_{\text {min }}=0,8 \frac{f_{c t d}}{f_{y d}} \\
& \rho_{\text {max }}=0,85\left(0,85 k_{1} \cdot \frac{f_{c d}}{f_{y d}} \cdot\left(\frac{600}{600+f_{y d}}\right)\right)
\end{aligned}
$$

\section{YAPAY ARI KOLONİ ALGORITTMASI (ARTIFICIAL BEE COLONY ALGORITHM)}

Yapay arı koloni (ABC) algoritması, arıların yiyecek arama davranışını modellemek için Karaboga [1] tarafindan önerilmiş sezgisel bir optimizasyon algoritmasıdır. Algoritma ilk olarak kısıtsız optimizasyon problemlerini çözmek için ortaya atılmasına karşın, Karaboga ve Basturk [27] tarafindan kısıtlı optimizasyon problemlerinin çözümü için geliştirilmiştir. İlerleyen yıllarda ise yakınsama hızının zayıf olmasından dolayı, algoritma üzerinde modifikasyon çalışmaları gerçekleştirilmiştir [28, 29]. ABC algoritması, işçi arılar, gözcü arılar ve kâşif arılar olmak üzere üç gruptan oluşmaktadır. İşçi arılar koloninin yarısını oluştururlar. Bu arılar, nektarı kovana getirmek ve nektar kaynağının kalitesi hakkında kovanda bekleyen gözcü arılara bilgi vermekle sorumludurlar. Gözcü arılar, işçi arılardan aldıkları bilgiye dayalı olarak, öğrendikleri yiyecek kaynağ çevresinde yeni kaynaklar aramaktadırlar. Kâşif arılar ise içsel dürtüler veya dış etkenlere bağlı olarak yeni yiyecek kaynakları bulabilmek için rastgele kaynak arayışına girmektedirler. Diğer sürü tabanlı arama algoritmalarında olduğu gibi, ABC algoritması da iteratif bir süreç takip etmektedir. Algoritma ilk olarak, çözüm uzayında rastgele dağılmış başlangıç popülasyonu üretmektedir. Rastgele yer belirleme aşaması, her bir tasarım değişkeninin alt sınırları $\left(\mathrm{x}_{\mathrm{j}}^{\mathrm{min}}\right)$ ve üst sınırları $\left(\mathrm{x}_{\mathrm{j}}^{\text {max }}\right)$ içerisinde kalacak şekilde Eş. 16'ya göre gerçekleşmektedir.

$x_{j}^{i}=x_{j}^{\min }+\operatorname{rand}(0,1) \times\left(x_{j}^{\max }-x_{j}^{\min }\right)$

Burada, i indisi, i. yiyecek kaynağını, başka bir deyişle i. işçi arıy ifade etmektedir $(\mathrm{i}=1,2, \ldots, \mathrm{SN})$. $\mathrm{j}$ indisi, $\mathrm{j}$. tasarım değişkenini göstermektedir $(\mathrm{j}=1,2, \ldots, \mathrm{D}) . \mathrm{SN}$, popülasyondaki işçi arı sayısı; D, tasarım değişkenleri sayısı; $\operatorname{rand}(0,1)$ ise $[0,1]$ aralığında seçilen rastgele bir sayıdır. $x_{j}$ vektörü D-boyutlu çözüm uzayında bir noktayı tarif etmektedir. Başlangıç sürecinden sonra, algoritma iterasyon sürecine başlar ve yeni çözümler geliştirmek için kullanılan işçi arılar, mevcut yiyecek kaynağının komşuluğundaki yeni kaynakların $\left(\mathrm{v}_{\mathrm{j}}^{\mathrm{i}}\right)$ yerlerini Eş. 17'ye göre belirlerler. Kısıtlı optimizasyon problemlerinin çözümü için Karaboga ve Akay [28] tarafindan önerilen modifiye ABC algoritmasında, işçi arının hafızasındaki mevcut yiyecek kaynağ $1\left(\mathrm{x}_{\mathrm{j}}^{\mathrm{i}}\right)$ ile yeni yiyecek kaynağının $\left(\mathrm{v}_{\mathrm{j}}^{\mathrm{i}}\right)$ kalitesinin karşılaştırılması ve seçim işlemi Deb'in kuralına göre yapılmaktadır [28, 30].

$v_{j}^{i}=\left\{\begin{array}{cl}x_{j}^{i}+\Phi_{j}^{i}\left(x_{j}^{i}-x_{j}^{k}\right) & , R_{j}<M R \\ x_{j}^{i} & , R_{j} \geq M R\end{array}\right.$

Burada, $\mathrm{k}$ indisi, i'den farklı ve 1 ile $\mathrm{SN}$ arasında rastgele bir yiyecek kaynağıdır. $\Phi_{j}{ }_{j},[-1,1] ; R_{j}$ ise $[0,1]$ aralığında üniform dağılmış rastgele reel bir sayıdır. MR, modifikasyon oranı ise modifiye ABC algoritmasının bir kontrol parametresi olup [0,1] arasında seçilen reel bir sayıdır [28].

Tüm işçi arılar arama sürecini tamamladıktan sonra, yiyecek kaynaklarının kalitesi ve yerleri ile ilgili bilgileri gözcü arılar ile paylaşırlar. Gözcü arılar ise Eş. 18'de tanımlanan uygunluk değerleri (fitness $\mathrm{i}_{\mathrm{i}}$ ) ve ihlal değerlerine (violation $\mathrm{i}_{\mathrm{i}}$ ) bağlı olarak rulet tekeri yöntemi ile Eş. 19'da hesaplanan olasılık değerlerine göre arama yapacakları kaynak için olasıl1ksal seçme işlemi yaparlar.

$$
\begin{aligned}
& \text { fitness }_{i}=\left\{\begin{array}{cc}
1 /\left(1+f_{i}\right) & , f_{i} \geq 0 \\
1+\operatorname{abs}\left(f_{i}\right) & , f_{i}<0
\end{array}\right. \\
& P_{i}= \begin{cases}0,5+\left(\frac{\text { fitness }_{i}}{\sum_{j=1}^{S N} \text { fitness }_{j}}\right) \times 0,5 & \text {,fizible çözüm ise } \\
\left(1-\frac{\text { violation }_{i}}{\sum_{j=1}^{\text {SN } \text { violation }_{j}}}\right) \times 0,5 & \text {,infizible çözüm ise }\end{cases}
\end{aligned}
$$

Burada, $\mathrm{f}_{\mathrm{i}}$, amaç fonksiyonunun değerini göstermektedir. violation $_{i}$ değeri $x_{i}$ vektörü çözümü için aşılan sınır değerlerinin toplamıdır. fitness $s_{i}$ değeri ise kaynağın nektar 
miktarının uygunluğunu ifade etmekte olup, uygunluk değerinin artması o kaynağın seçilme olasılı̆̆ının da artacağı anlamına gelmektedir. Gözcü arılar da tıpkı işçi arılar gibi, yiyecek kaynağı etrafinda Eş. 17 ile belirtilen ifadeye göre yeni yiyecek kaynakları aramaktadırlar. Yeni çözümler ile eski çözümleri karşılaştırırlar ve daha iyi çözümleri hafızasında tutarlar. Eğer Eş. 17 ile belirlenen noktadaki amaç değeri çözümde bir iyileştirme sağlayamıyorsa, hata değeri 1 artırılır. Hata değerinin, algoritmanın önemli parametrelerinden biri olan limit değerini aşması durumunda, o yiyecek kaynağ çözümün bulunamadığı kanaatine varılır ve ilgili arı da kâşif arıya dönüşür.

Modifiye ABC algoritmasının son aşaması kâşif arı sürecidir. Kâşif arılar, Eş. 16'da tanımlanan ifadeye göre rastgele çözümler aramaya başlarlar. Tanımlanan bu aşamalar maksimum döngü sayısı (MCN) kadar tekrarlanarak elde edilen en iyi çözüm kaydedilir ve algoritma sonlandırılır. $\mathrm{Bu}$ çalışmada kullanılan ABC algoritmasına ait akış diyagramı Şekil 3'de verilmiştir.

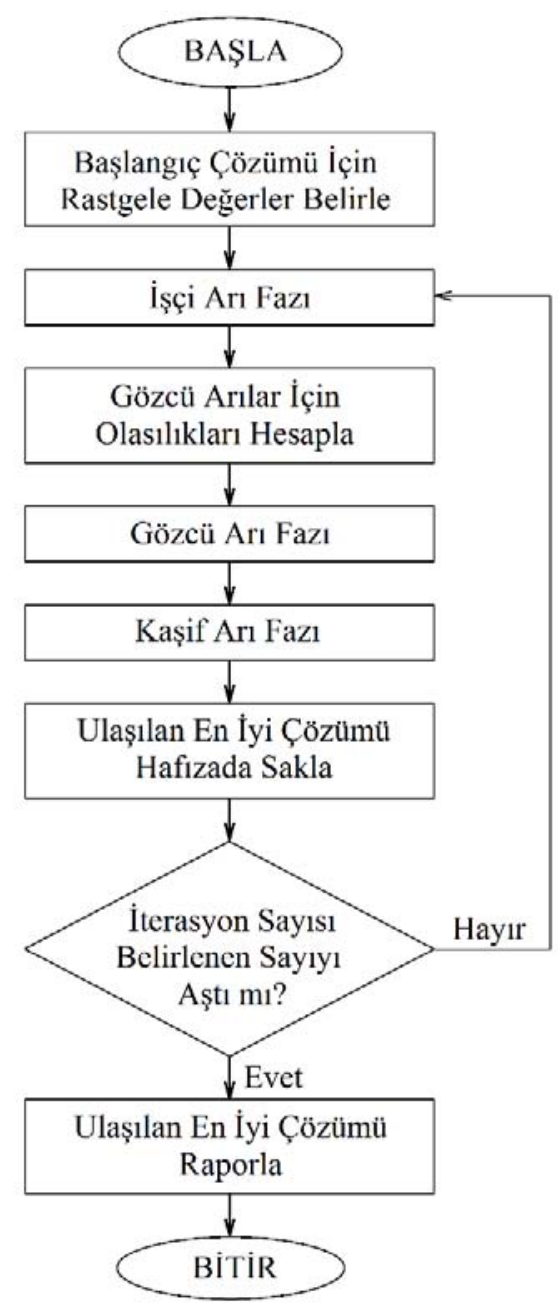

Şekil 3. ABC algoritması akış diyagramı (The flowchart of ABC algorithm)

\section{OPTIMIZASYON PROBLEMININ TANIMLANMASI (DEFINITION OF OPTIMIZATION PROBLEM)}

$\mathrm{Bu}$ çalışma kapsamında, betonarme istinat duvarı tasarımı için tasarım değişkenleri duvar kesitinin geometrik boyutları ve donatı oranları olarak iki gruba ayrılmıştır. Şekil 1.b'de gösterilen ve Tablo 1'de tanımlanan bu tasarım değişkenlerinin ilk 5 tanesi $\left(\mathrm{x}_{1}, \mathrm{x}_{2}, \mathrm{x}_{3}, \mathrm{x}_{4}, \mathrm{x}_{5}\right)$ geometrik tasarım değişkeni, diğerleri $\left(\mathrm{x}_{6}, \mathrm{x}_{7}, \mathrm{x}_{8}\right)$ ise donatı oranı tasarım değişkenidir. İmalat ve teorik gereksinimlerden dolayı, tasarım değişkenleri belirli alt ve üst sınırlar arasında kalmalıdır. Örneğin, betonun kolay yerleşimini sağlayabilmek için gövdenin üst genişliği $\left(\mathrm{x}_{1}\right)$ genellikle en az $0,3 \mathrm{~m}$ olarak seçilmeli $[25,31]$, donatı oranları ise kullanılan malzemenin özelliklerine bağlı olarak Eş. 14 ve Eş. 15'de tanımlanan alt ve üst sınırlar arasında kalmalıdır. $\mathrm{Bu}$ sınır değerlerini kullanmak tasarımda uygulanabilir değerler elde etmenin yanı sıra optimizasyon probleminde daha hızlı sonuç elde etmeye de katkı sağlayacaktır. Bu nedenle, Tablo 1'de görüleceği üzere, tüm tasarım değişkenleri için alt ve üst sınırlar tanımlanmıştır. Betonarme istinat duvarı optimizasyon problemindeki tasarım gereksinimleri ise üç kategori olarak gruplandırılmıştır. Bunlar, dış stabilite yenilme kısıtları, iç stabilite yenilme kısıtları ve ilave geometrik kısıtlardır. Optimizasyon problemi için normalize edilmiş tasarım kısıtları Tablo 2'de verilmiştir. Dolgu zemini ve temel zemininin özellikleri, dış yükler, minimum güvenlik sayıları, beton ve çelik sınıflarının seçimi ise girdi parametreleri olarak düşünülmüştür. Tablo 3 'de verilen bu girdi parametreleri optimizasyon sürecinde sabit tutulmuştur. $\mathrm{Bu}$ çalışmada, betonarme istinat duvarının optimum tasarımı için amaç fonksiyonu, en düşük maliyetli istinat duvarı elde etmek olarak belirlenmiş ve Eş. 20'de verilmiştir. Problemi basitleştirebilmek için kazı, dolgu, sıkıştırma, kalıp işçilikleri ve malzeme kaybı gibi maliyetler ihmal edilmiştir.

$f(x)=C_{s t} \cdot W_{s t}+C_{c} \cdot V_{c, n e t}$

Burada;

$\mathrm{C}_{\text {st }}$ ve $\mathrm{C}_{\mathrm{c}}$, sırasıyla, donatı çeliği ve betonun birim maliyetidir. Bu çalışmada, Saribas ve Erbatur [8] tarafindan kullanılan ve 2016 yılı birim fiyatlarına da oldukça yakın olan $0,40 \$ / \mathrm{kg}$ ve $40 \$ / \mathrm{m}^{3}$ değerleri seçilmiştir. $W_{\text {st }}$, duvarın birim uzunluğu için donatı çeliği ağırlığ $; V_{c \text {,net }}$ ise duvarın birim uzunluğu için net beton hacmidir.

\section{SONUÇLAR VE TARTIŞMALAR (RESULTS AND DISCUSSIONS)}

Bu çalışmada, sağlam temel zemini koşulları üzerindeki betonarme istinat duvarlarının minimum maliyeti üzerinde dolgunun içsel sürtünme açısı $\left(\phi_{1}\right)$, sürşarj yükü (q), duvar yüksekliği $(H)$ ve pasif direnç $(\alpha)$ etkileri araştırılmıştır. Optimizasyon problemi için girdi parametreleri Tablo 3'de verilmiş olup, uygulamada karşılaşılan gerçek parametre değerlerini içeren aralıklar dikkate alınarak farklı dolgu içsel 
Tablo 1. Tasarım değişkenlerinin tanımı, alt ve üst sınırları (Definition, lower and upper bounds of design variables)

\begin{tabular}{llll}
\hline Tasarım Değişkeni & Tanımlama & Alt Sınır & Üst Sınır \\
\hline $\mathrm{x}_{1}$ & Gövdenin üstteki genişliği & 0,3 & 1,0 \\
$\mathrm{x}_{2}$ & Burun genişliği & 0,3 & 5,0 \\
$\mathrm{X}_{3}$ & Gövdenin alttaki genişliği & 0,3 & 5,0 \\
$\mathrm{X}_{4}$ & Topuk genişliği & 0,3 & 5,0 \\
$\mathrm{X}_{5}$ & Temelin kalınlığ1 & 0,3 & 2,0 \\
$\mathrm{x}_{6}$ & Burun için ana donatı oranı & Eş. 14 & Eş. 15 \\
$\mathrm{x}_{7}$ & Topuk için ana donatı oranı & Eş. 14 & Eş. 15 \\
$\mathrm{x}_{8}$ & Gövde için ana donatı oranı & Eş. 14 & Eş. 15 \\
\hline
\end{tabular}

Tablo 2. Normalize edilmiş tasarım kısıtları (Normalized design constraints)

\begin{tabular}{ll}
\hline Tasarım K1sitlar1 & Tanımlama \\
\hline$g_{1}(X)=F S_{(d, \text { min })} / F S_{(\text {devrilme })}-1 \leq 0$ & Devrilme yenilmesi \\
$g_{2}(X)=F S_{(k, \text { min })} / F S_{(\text {kayma })}-1 \leq 0$ & Kayma yenilmesi \\
$g_{3}(X)=F S_{(t, \text { min })} / F S_{(\text {tasima })}-1 \leq 0$ & Taşıma gücü yenilmesi \\
$g_{4}(X)=1 / F S_{(\text {cekme })}-1 \leq 0$ & Eksantrisite yenilmesi \\
$g_{5}(X)=M_{d, \text { govde }} / M_{r, \text { govde }}-1 \leq 0$ & Gövde moment yenilmesi \\
$g_{6}(X)=V_{d, \text { govde }} / V_{r, \text { govde }}-1 \leq 0$ & Gövde kesme yenilmesi \\
$g_{7}(X)=M_{d, \text { burun }} / M_{r, \text { burun }}-1 \leq 0$ & Burun moment yenilmesi \\
$g_{8}(X)=V_{d, \text { burun }} / V_{r, \text { burun }}-1 \leq 0$ & Burun kesme yenilmesi \\
$g_{9}(X)=M_{d, \text { topuk }} / M_{r, \text { topuk }}-1 \leq 0$ & Topuk moment yenilmesi \\
$g_{10}(X)=V_{d, \text { topuk }} / V_{r, \text { topuk }}-1 \leq 0$ & Topuk kesme yenilmesi \\
$g_{11}(X)=1-50\left(x_{3}-x_{1}\right) /\left(H-x_{5}\right) \leq 0$ & Geometrik kisit \\
$g_{12}(X)=x_{5} / H-1 \leq 0$ & Geometrik kısit \\
\hline
\end{tabular}

Tablo 3. Optimizasyon problemi için girdi parametreleri ve analizlerde kullanılan değerler (The input parameters for optimization problem and the values used in analysis)

\begin{tabular}{ll}
\hline Girdi parametreleri & Kullanılan değerler \\
\hline Duvarın yüksekliği $(\mathrm{H})$ & $4 ; 5 ; 6 ; 7 ; 8 \mathrm{~m}$ \\
Sürşarj yükü $(\mathrm{q})$ & $0 ; 10 ; 20 ; 30 ; 40 \mathrm{kPa}$ \\
Dolgu için içsel sürtünme açısı $\left(\phi_{1}\right)$ & $28 ; 30 ; 32 ; 34 ; 36 \square$ \\
Pasif direnç etki katsayısı $(\alpha)$ & $0 ; 0,3333 ; 0,6667 ; 1$ \\
Duvarın önündeki zemin yüksekliği $\left(\mathrm{D}_{\mathrm{f}}\right)$ & $1 \mathrm{~m}$ \\
Temel zemini için içsel sürtünme açısı $\left(\phi_{2}\right)$ & $30 \square$ \\
Temel zemini için kohezyon $\left(\mathrm{c}_{2}\right)$ & $200 \mathrm{kPa}$ \\
Dolgunun birim hacim ağırlığı $\left(\gamma_{1}\right)$ & $17 \mathrm{kN} / \mathrm{m}^{3}$ \\
Temel zemininin birim hacim ağırlığı $\left(\gamma_{2}\right)$ & $18 \mathrm{kN} / \mathrm{m}^{3}$ \\
Betonun birim hacim ağırlı̆̆ $1\left(\gamma_{\mathrm{c}}\right)$ & $23,5 \mathrm{kN} / \mathrm{m}^{3}$ \\
Betonun basıç dayanımı $\left(\mathrm{f}_{\mathrm{ck}}\right)$ & $25 \mathrm{MPa}$ \\
Çeliğin akma dayanımı $\left(\mathrm{f}_{\mathrm{yk}}\right)$ & $420 \mathrm{MPa}$ \\
Devrilmeye karşı güvenlik sayısı $\left(\mathrm{FS}_{\mathrm{d}, \min }\right)$ & 2,0 \\
Kaymaya karşı̈ güvenlik sayısı $\left(\mathrm{FS}_{\mathrm{k}, \min }\right)$ & 1,5 \\
Taşıma gücü için güvenlik sayısı $\left(\mathrm{FS}_{\mathrm{t}, \min }\right)$ & 3,0 \\
\hline
\end{tabular}

sürtünme açıları $\left(28^{\circ}-36^{\circ}\right)$, sürşarj yükleri $(0-40 \mathrm{kPa})$, duvar yükseklikleri $(4 \mathrm{~m}-8 \mathrm{~m})$ ve pasif direnç etki katsayıları $(0-1)$ için toplam 500 probleme ait analizler gerçekleştirilmiştir. İstinat duvarının oturacağı temel zeminin yüksek taşıma gücü kapasitesine sahip olduğunu modellemek için, temel zemininin kayma direnci parametreleri $\mathrm{c}_{2}=200 \mathrm{kPa}$ ve $\phi_{2}=30^{\circ}$ olarak seçilmiştir.

\subsection{Algoritmanın Kararlılı $\breve{l}$ (The Stability of the Algorithm)}

Kullanılan ABC algoritmasının parametre değerleri, koloni sayıs1, $C S=100$, modifikasyon oran $1, \mathrm{MR}=0,8$, limit $=400$ ve maksimum döngü sayısı, $\mathrm{MCN}=1000$ olarak seçilmiştir. Algoritmanın kararlılık, performans ve tekrarlanabilirliğini göstermek amacıyla gerçekleştirilen analizler sonrasında en 
iyi sonucun bulunduğu yiyecek kaynağı ile ona komşu diğer kaynakların birbirine yakınlı̆̆ test edilerek, her bireyin optimum değere yakınsayabilme yeteneği incelenmiştir. Algoritmanın rastgele seçilen bağımsız bir çalıştırılması sonucunda, 50 farklı işçi arının 1000 iterasyon sonunda ulaştığı fizibil noktaların amaç fonksiyonu değerleri grafik olarak Şekil 4'de sunulmuştur. Şekil 4 incelendiğinde, elde edilen amaç fonksiyonu değerlerinin dar bir aralıkta olduğu görülmektedir. Burada yer verilen örnek için, bağımsız bir çalıştırılması sonucunda bireylerin amaç fonksiyonu değerlerine ait varyasyon katsayısı \%1 civarındadır. Optimizasyon uygulamalarında, bu bireyler içerisinden en uygun amaç fonksiyonunun elde edildiği çözüm (minimum maliyet), analiz sonucu olarak raporlanmaktadır.

Algoritmaya yönelik olarak gerçekleştirilen diğer bir analiz grubunda ise, her bir problem için optimizasyon analizi birbirinden bağımsız rastgele popülasyonlardan başlanarak
30 kez tekrarlanmıştır. Aynı problemin birbirinden bağımsız 30 kez çözülmesi sonucunda, duvar maliyetinin elde edilen en iyi, en kötü, ortalama, standart sapma ve varyasyon katsayısı değerleri seçilen dört problem için Tablo 4'de verilmiştir. Aynı değerlendirmeler diğer optimizasyon problemleri için de elde edilmiş ve benzer bulgulara ulaşıldığ 1 için ayrıca verilmemiştir. Tablo 4, her bir problem için birbirinden bağımsız 30 analiz sonucunda elde edilen duvar maliyeti değerleri arasında önemli bir farklılığın olmadığını ve ele alınan 500 optimizasyon problemi için varyasyon katsayısının \%0,5'in altında kaldığını göstermektedir. Bu değerlendirmeler sonunda, algoritmanın oldukça yüksek bir performans ve tekrarlanabilirliğe sahip olduğuna karar verilmiştir.

Aşağıdaki bölümlerde yapılacak olan değerlendirmelerde, her bir problem için gerçekleştirilen 30 bağımsız analize ait sonuçların ortalamaları dikkate alınmıştır.

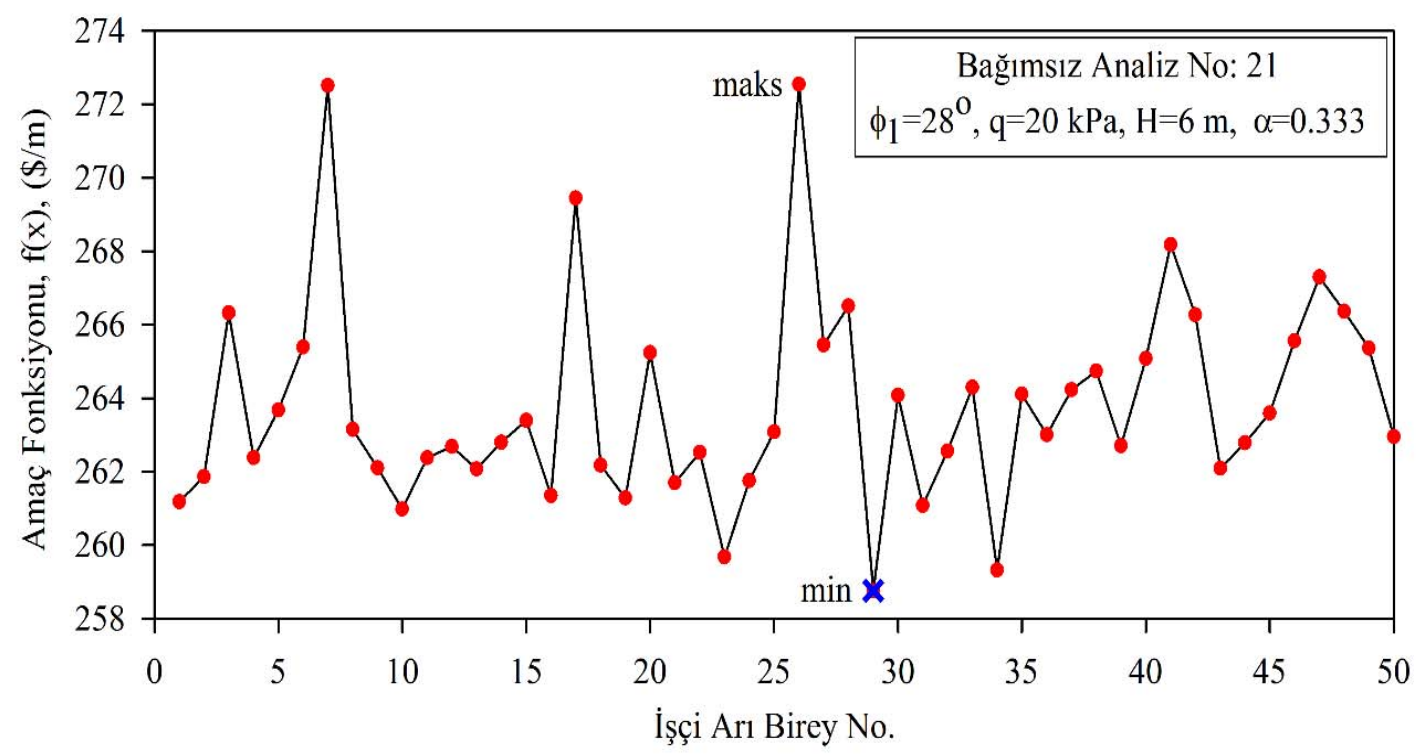

Şekil 4. Bağımsız bir analiz için bireylerin en iyi çözümleri (The best solutions of the individuals for an independent analysis)

Tablo 4. Seçilen problemler için 30 bağımsız analiz sonucunda elde edilen duvar maliyetinin değişkenliği (The variability of the cost of the wall obtained from the results of 30 independent analyses for some problems)

\begin{tabular}{lccccc}
\hline Problem & $\begin{array}{c}\text { En İyi } \\
(\$ / \mathrm{m})\end{array}$ & $\begin{array}{c}\text { En Kötü } \\
(\$ / \mathrm{m})\end{array}$ & $\begin{array}{c}\text { Ortalama } \\
(\$ / \mathrm{m})\end{array}$ & $\begin{array}{c}\text { Std. Sap. } \\
(\$ / \mathrm{m})\end{array}$ & $\begin{array}{c}\text { Var. Kts. } \\
(\%)\end{array}$ \\
\hline $\begin{array}{l}\phi_{1}=32^{\circ}, \mathrm{q}=30 \mathrm{kPa}, \mathrm{H}=5 \mathrm{~m}, \\
\alpha=0,667\end{array}$ & 187,953 & 191,055 & 189,269 & 0,721 & 0,38 \\
$\phi_{1}=28^{\circ}, \mathrm{q}=20 \mathrm{kPa}, \mathrm{H}=6 \mathrm{~m}$, & 258,679 & 261,774 & 260,258 & 0,918 & 0,35 \\
$\alpha=0,333$ & & & & \\
$\phi_{1}=34^{\circ}, \mathrm{q}=40 \mathrm{kPa}, \mathrm{H}=7 \mathrm{~m}$, & 365,392 & 372,914 & 369,023 & 1,589 & 0,43 \\
$\alpha=0$ & & & & \\
$\phi_{1}=36^{\circ}, \mathrm{q}=10 \mathrm{kPa}, \mathrm{H}=8 \mathrm{~m}$, & 338,326 & 342,902 & 340,185 & 1,085 & 0,32 \\
$\alpha=1$
\end{tabular}




\subsection{Pasif Direnç Etkisi (Effect of the Passive Resistance)}

Çalışmada ilk olarak, duvar ön yüzünde yer alan doğal zemin üzerinde oluşacak pasif direncin etkisi ele alınmıştır. Uygulamada, zeminin aşınma, taşınma gibi çevresel etkilere maruz kalabileceği düşüncesiyle genellikle pasif dirençler ihmal edilmektedir. Ancak, kaymaya karşı güvenliğin sağlanamadığ 1 durumlarda ise bunun tam tersine temel altında oluşturulan dişler sayesinde bu pasif direncin artırılması hedeflenmektedir. Buna ilave olarak, pasif direncin tam olarak oluşabilmesi için gerekli duvar hareketinin de çoğu zaman sağlanabilmesi mümkün gözükmemektedir. $\mathrm{Bu}$ nedenle, bu çalışma kapsamında tanımlanan pasif direnç etki katsayısı $(\alpha)$ ile pasif direncin ihmali veya $1 / 3$ 'ü, 2/3'ü ya da tamamının oluşması durumları için optimizasyon analizleri gerçekleştirilmiştir. İstinat duvarı temellerinin sağlam zemin tabakası üzerinde yer aldığı düşünüldüğünde, tüm problemlerde pasif direnç etki katsayısının $(\alpha)$ minimum maliyete etkisinin benzer sonuçlar vermesi sebebiyle Şekil 5'de sadece birkaç örnek için değerlendirme yapılmıştır. Şekil 5.a, $\mathrm{H}=4 \mathrm{~m}, \phi_{1}=28^{\circ}$ ve farklı sürşarj yükleme durumları için, Şekil 5.b ise $\mathrm{H}=6 \mathrm{~m}$, $\mathrm{q}=30 \mathrm{kPa}$ ve farklı içsel sürtünme açısına sahip dolgular için pasif direnç etki katsayısı ve minimum duvar maliyeti arasındaki ilişkiyi göstermektedir. Pasif direncin ihmali ile tam olarak oluşması kabulleri arasında, optimizasyon problemlerinin tamamında, maliyet değişiminin \%0,34'ün altında kaldığı görülmektedir. Yukarıda bahsedildiği üzere, aynı problem için 30 bağımsız analizin gerçekleştirilmesinde dahi varyasyon katsayısının \%0,5 civarlarında olması, pasif direncin etkisinden kaynaklanan bu değişimin esasen algoritmanın rastgeleliğinden kaynaklandığını düşündürmektedir. Şekil 5'den görüleceği üzere, sağlam zemin tabakalarına oturan istinat duvarlarının minimum maliyetinin pasif dirençten bağımsız olduğu anlaşılmaktadır. $\mathrm{Bu}$ durum, temel zemininin kayma direnci parametrelerinin

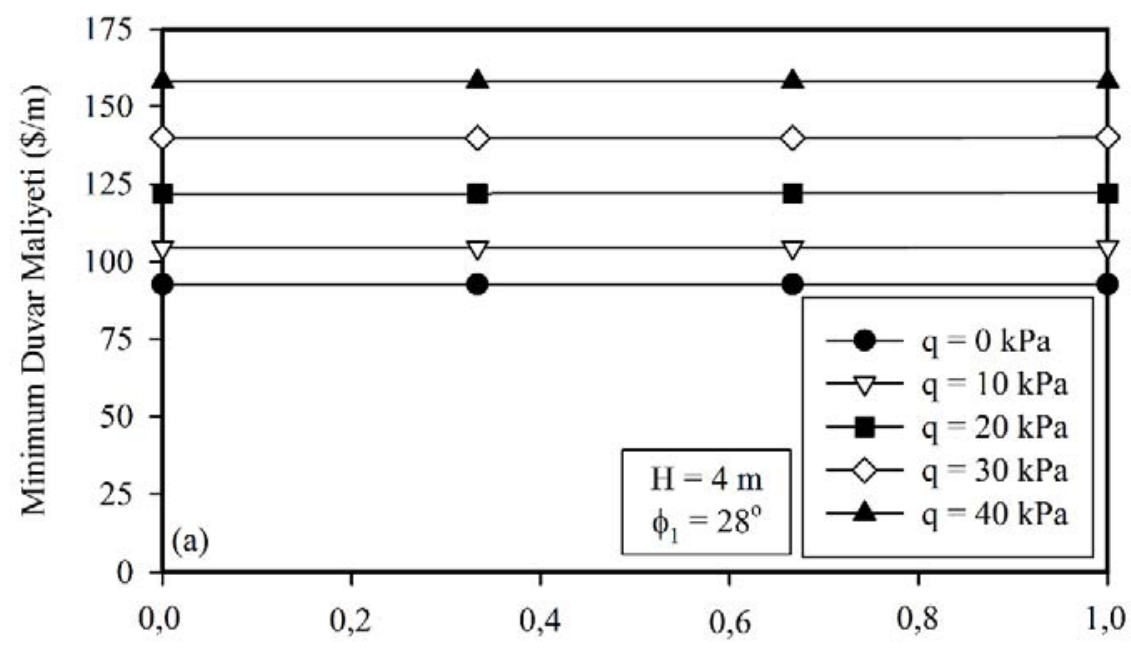

Pasif Direnç Etki Katsayısı, $\alpha$

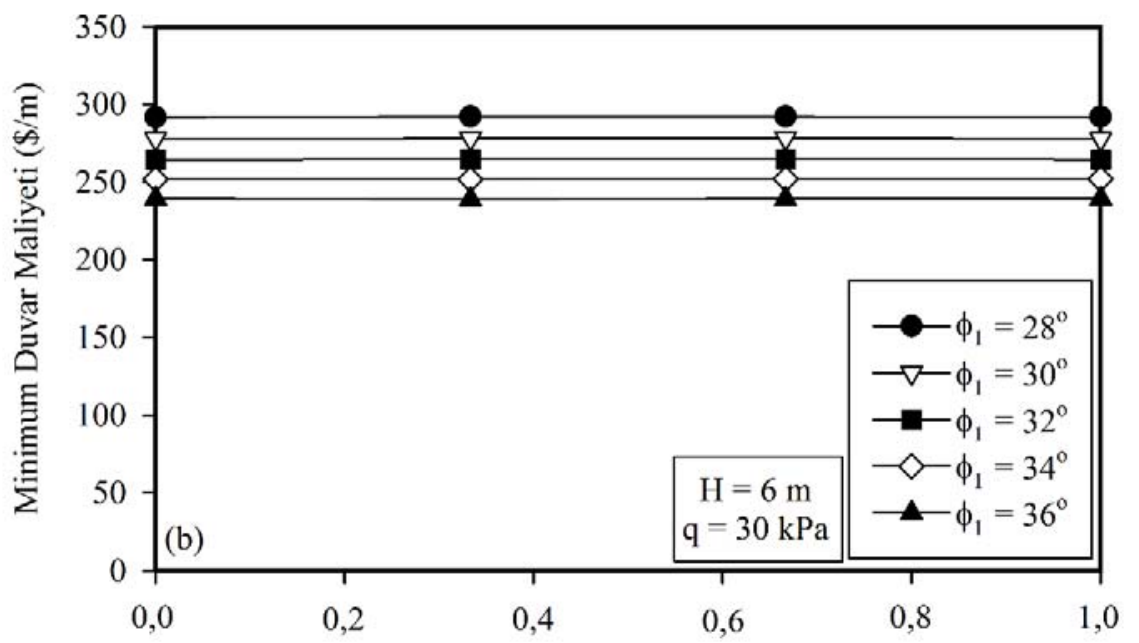

Pasif Direnç Etki Katsayısı, $\alpha$

Şekil 5. Minimum duvar maliyeti üzerinde pasif direnç etkisi

(The effect of passive resistance on the minimum cost of the wall) 
kaymaya karşı gerekli direnci sağlamak için yeterli olduğunu ve pasif direncin varlığının gerekli olmadığını göstermektedir. $\mathrm{Bu}$ nedenle, uygulamada, istinat duvarı temellerinin yüksek taşıma gücüne sahip zemin tabakalarına oturtulmaları halinde pasif direncin hesaba katılması veya ihmal edilmesi duvar maliyetini etkilemeyecektir. Sağlam temel zeminine oturan istinat duvarlarının maliyeti üzerinde pasif direncin etkisinin olmadığı tespitine dayanarak, bu kısımdan sonra yapılacak olan tüm değerlendirmelerde pasif direncin ihmal edildiği $(\alpha=0)$ durumlara ait analiz sonuçları kullanılacaktır. Ayrıca, dolgunun içsel sürtünme açısı ve sürşarj yükünün etkisini incelemek için, sabit duvar yükseklikleri altında maliyet değerlendirmeleri yapılacaktır.

\subsection{Dolgunun İçsel Sürtünme Açısının Etkisi (Effect of the Internal Friction Angle of Backfill)}

Duvar arkasında kullanılacak olan dolgu malzemesinin sıkılığı yanal toprak basıncının büyüklüğünü etkileyen önemli parametrelerden birisidir. Dolgunun sıkılığının artması, içsel sürtünme açısının da artacağı ve yanal toprak basınçlarının azalacağı anlamına gelmektedir. Bunun da duvar maliyetini azaltması beklenir. Şekil 6' da farklı sürşarj yükleri için dolgunun içsel sürtünme açısı ile minimum duvar maliyetinin değişimi gösterilmektedir. Sabit duvar yüksekliği ve sürşarj yükü için dolgunun içsel sürtünme açısının artışıyla beraber duvarın toplam maliyetinin düştüğü görülmektedir. Tüm duvar yükseklikleri için bu azalım
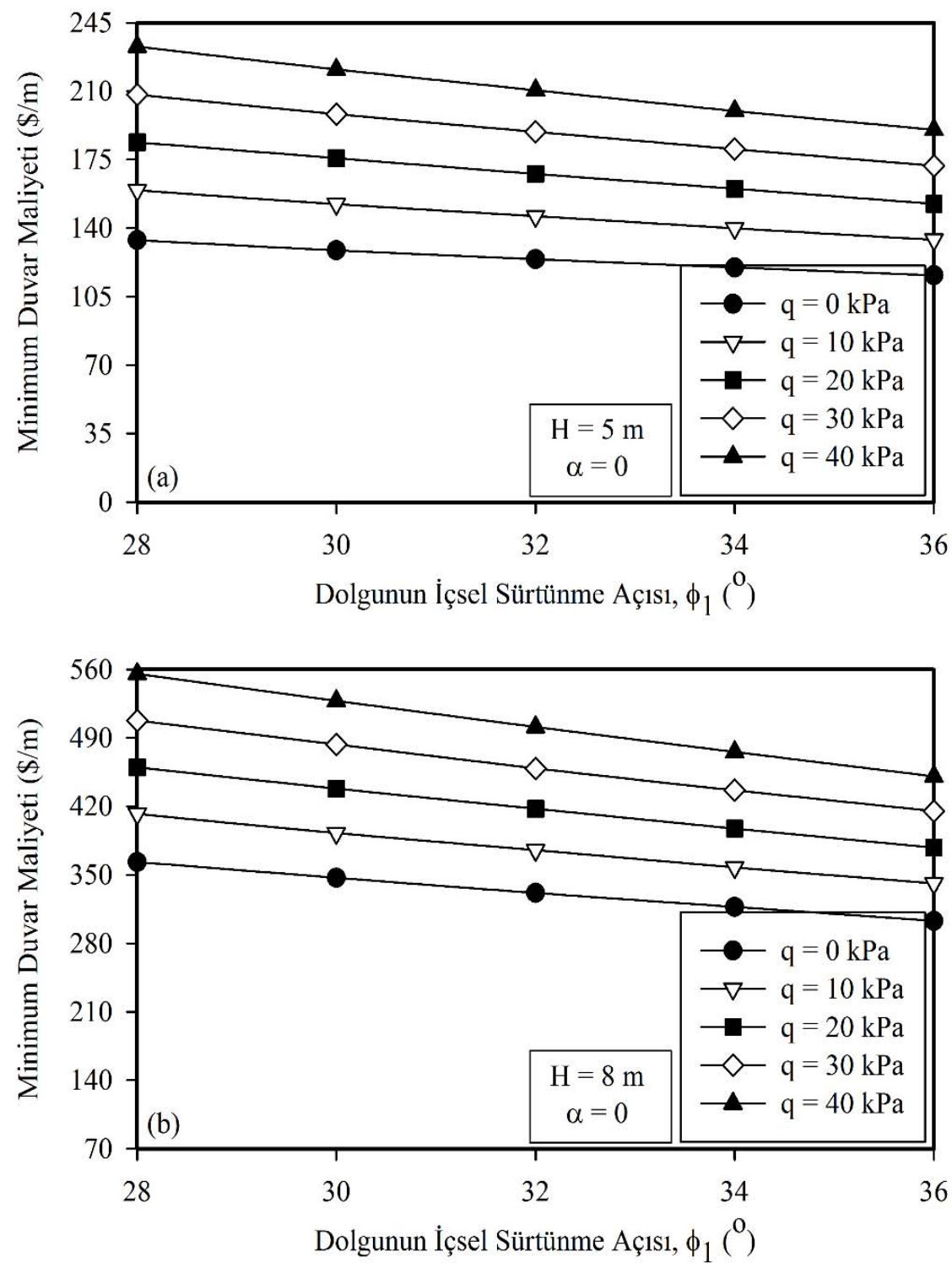

Şekil 6. Duvar maliyeti üzerinde dolgunun içsel sürtünme açısının etkisi (The effect of internal friction angle of backfill on the cost of the wall) 
eğilimi lineer formda olup, Şekil 6' da $\mathrm{H}=5 \mathrm{~m}$ ve $\mathrm{H}=8$ m'lik duvarlara ait sonuçlar örneklenmiştir. Eğilim ölçüsü değerlendirildiğinde ise dolgunun içsel sürtünme açısının $28^{\circ}$ 'den $36^{\circ}$ 'ye yükselmesi, tüm duvar yükseklikleri ve sürşarj yükleri için duvar maliyetinin \%13,4 ile \%18,9 arasında (ortalama olarak \%17) azaldığını göstermektedir.

\subsection{Sürşarj Yükünün Etkisi (Effect of the Surcharge Load)}

İstinat duvarının arkasındaki zemin üzerinden araçların geçmesi, malzeme depolanması veya bir yapının bulunması, yanal toprak itkisinin dışında düzgün yayıldığı kabul edilen ve sürşarj yükü olarak tanımlanan ilave yükler oluşturmaktadır. İnşa edilecek olan istinat duvarlarının arkasında bir sürşarj yükü bulunmasa dahi, herhangi bir olağanüstü yükleme durumunda problemle karşılaşılmaması için analizlerde minimum bir sürşarj yükünün dikkate alınması önerilmektedir [32]. Bu kısımda, sürşarj yükünün duvar maliyeti üzerindeki etkisi incelenmiş ve $\mathrm{H}=5 \mathrm{~m}$ ve $\mathrm{H}$ $=7 \mathrm{~m}$ yüksekliğindeki duvarlara ait sonuçlar Şekil 7'de verilmiştir. Sürşarj yükünün artışı duvarın minimum maliyetinde yaklaşık olarak lineer bir artışa sebep olmaktadır. $\mathrm{Bu}$ artışın büyüklüğü duvar yüksekliği ve dolgunun içsel sürtünme açısına bağlıdır. Örneğin, sürşarj yükü 0'dan 40 kPa'a arttığında, $\mathrm{H}=5 \mathrm{~m}$ yüksekliğindeki duvarın maliyetindeki artış $\phi_{1}=36^{\circ}$ için $\% 64$ iken, $\phi_{1}=28^{\circ}$ için \%74'e ulaşmaktadır. $\mathrm{H}=7$ m'lik duvar için ise bu artış sırasıyla \%54 ile \%58 Aralığında olmaktadır. Yani, duvar yüksekliğinin artışı ile birlikte, sürşarj yükünün duvar maliyeti üzerindeki etkisi dolgunun içsel sürtünme açısından bağımsız hale gelmektedir. Ayrıca, sürşarj yükünün her 10 kPa'lık artışı sonunda duvar maliyetinde ortalama \%12,7 civarında artışa sebep olmaktadır. Gerek dolgunun içsel sürtünme açısı gerekse sürşarj yükünün maliyet üzerindeki etkisinin lineer oluşu, üç boyutlu uzayda maliyet değişimi için bir düzlemin varlığını işaret etmektedir. Bu nedenle,

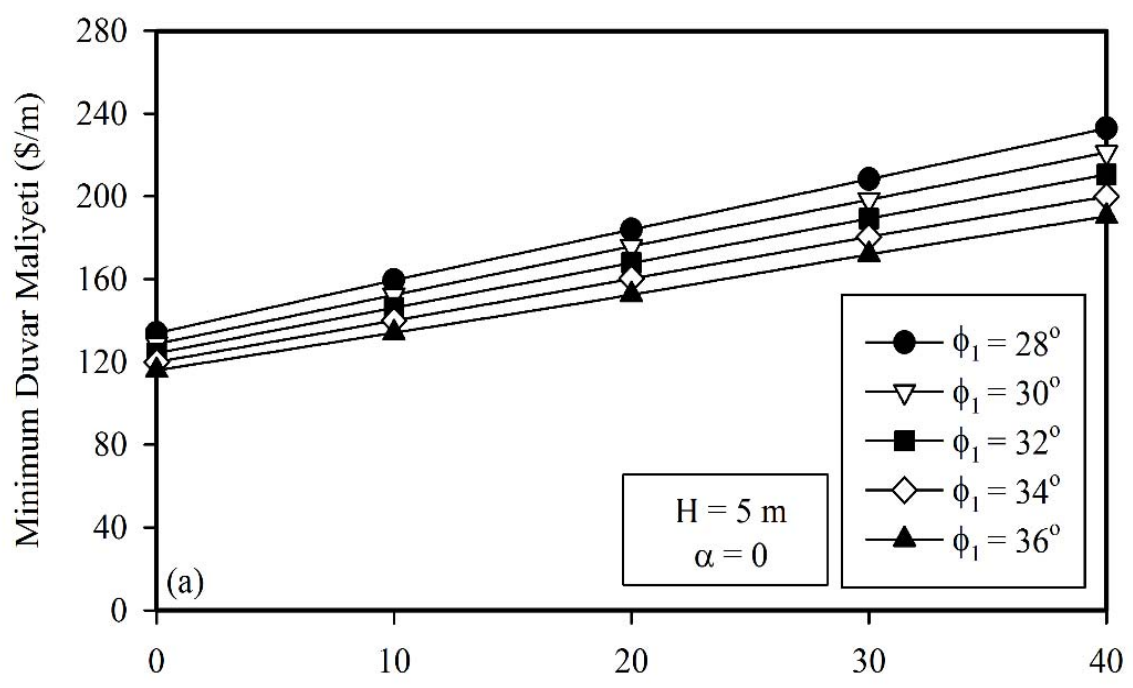

Sürsarj Yükü, q (kPa)

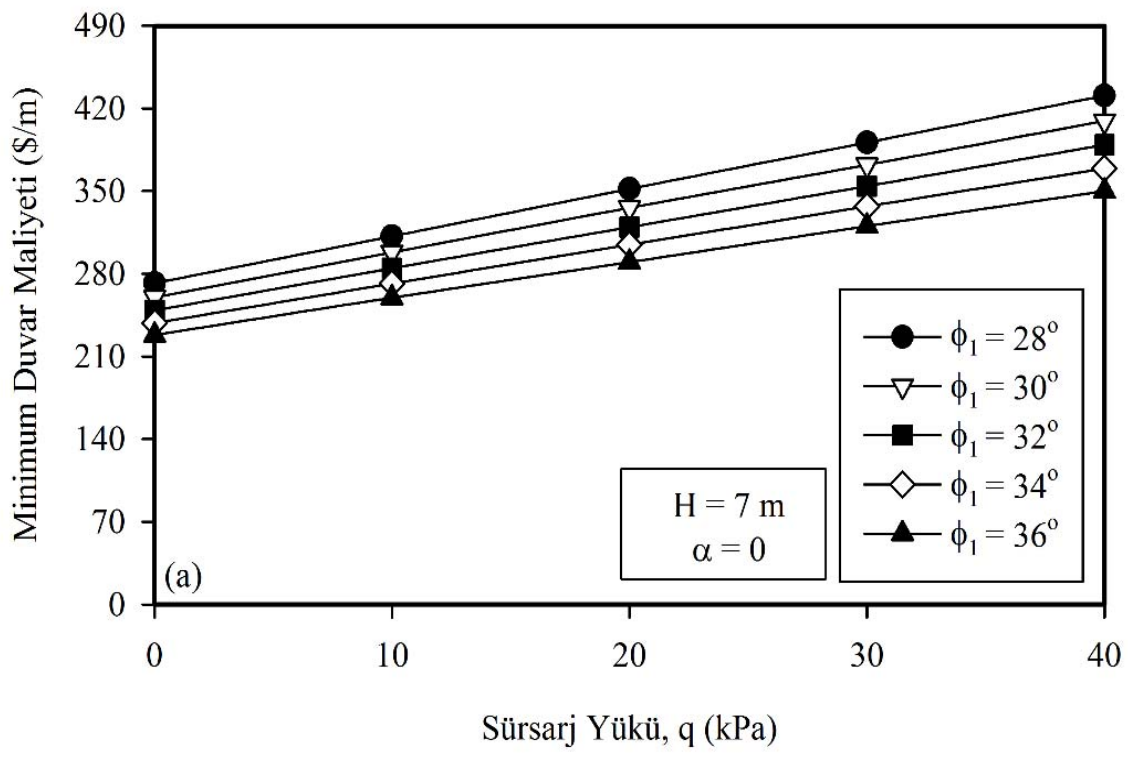

Şekil 7. Duvar maliyeti üzerinde sürşarj yükünün etkisi (The effect of surcharge load on the cost of the wall) 
dolgunun içsel sürtünme açısı ve sürşarj yükü, duvarın minimum maliyeti ile birlikte incelenerek Şekil 8 oluşturulmuştur. Şekil 8 'den görüleceği üzere, içsel sürtünme açısı ve sürşarj yüküne bağlı maliyet değişimi iki yönden eğimli bir düzlem şeklindedir.

\subsection{Duvar Yüksekliğinin Etkisi (Effect of the Height of Wall)}

Şekil 9'da q $=0$ ve $40 \mathrm{kPa}$ 'llk sürşarj yükleri için duvar yüksekliğinin artışı ile minimum duvar maliyetinin değişimi gösterilmektedir. Diğer parametrelerin maliyet ile olan
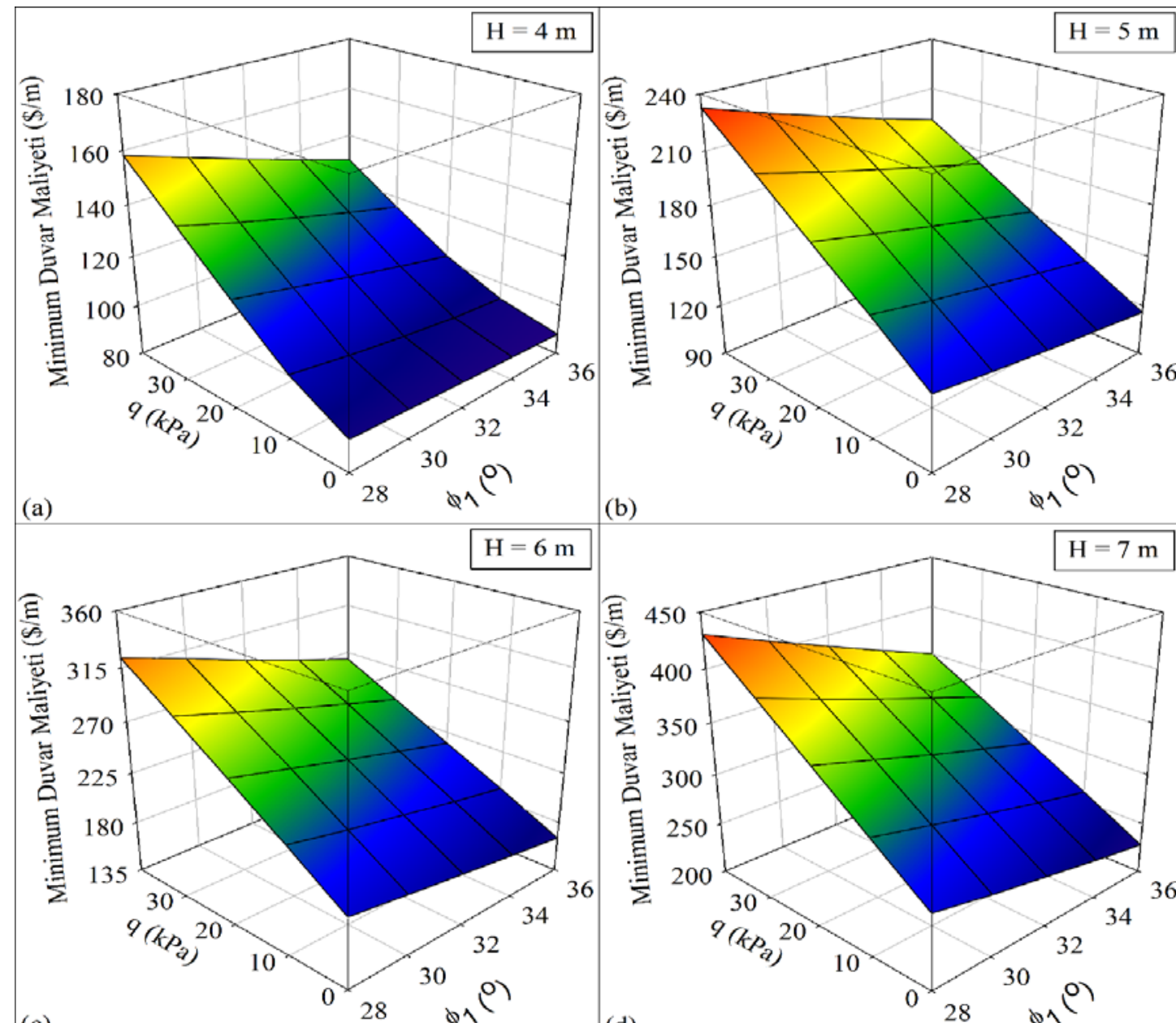

(b)

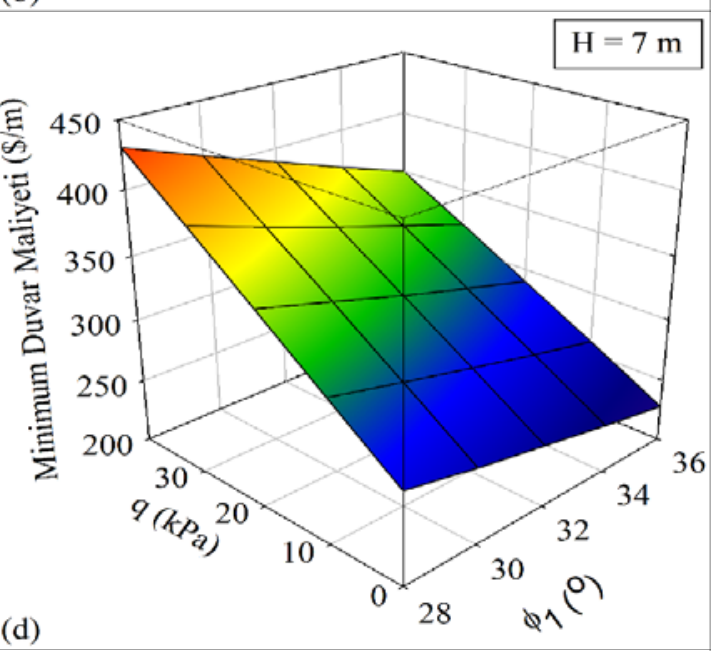

(c)

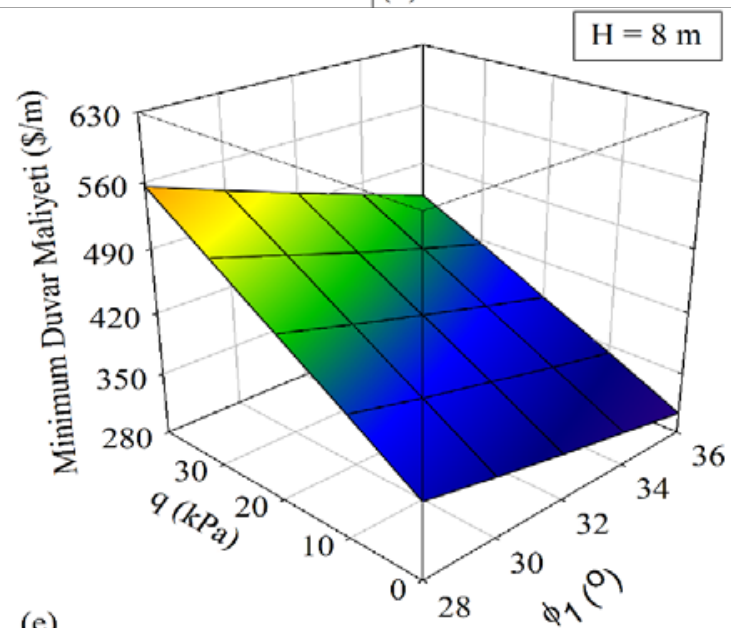

(e)

Şekil 8. Farklı duvar yükseklikleri için içsel sürtünme açısı, sürşarj yükü ve minimum duvar maliyeti ilişkisi (The relationship between the internal friction angle, surcharge load and the minimum cost of the wall for different heights of wall) 


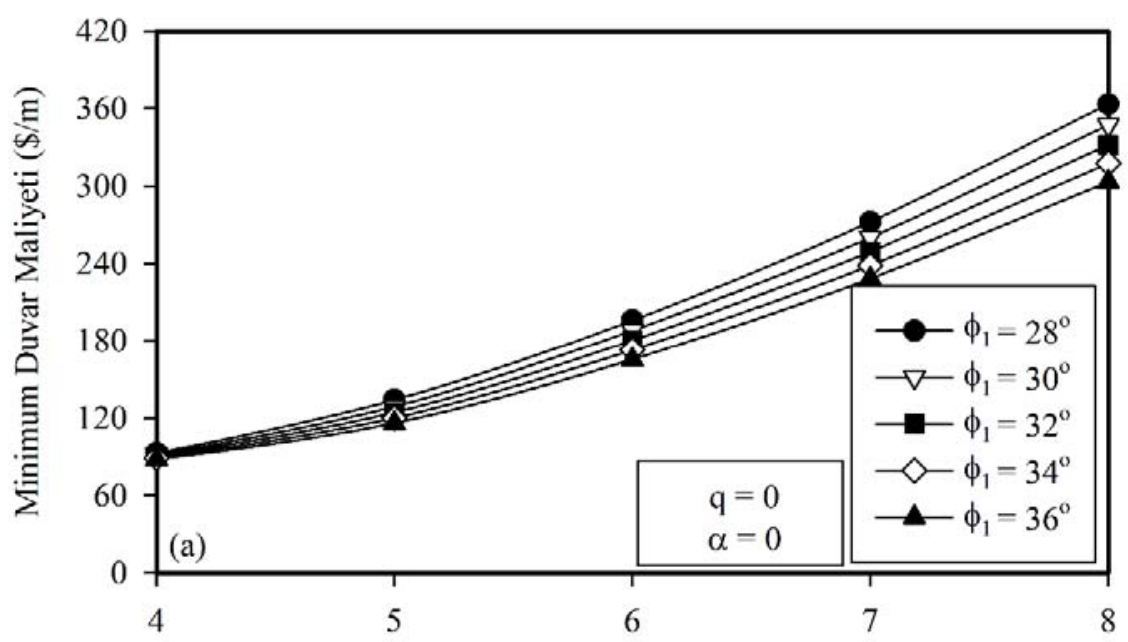

Duvar Yüksekliği, H (m)

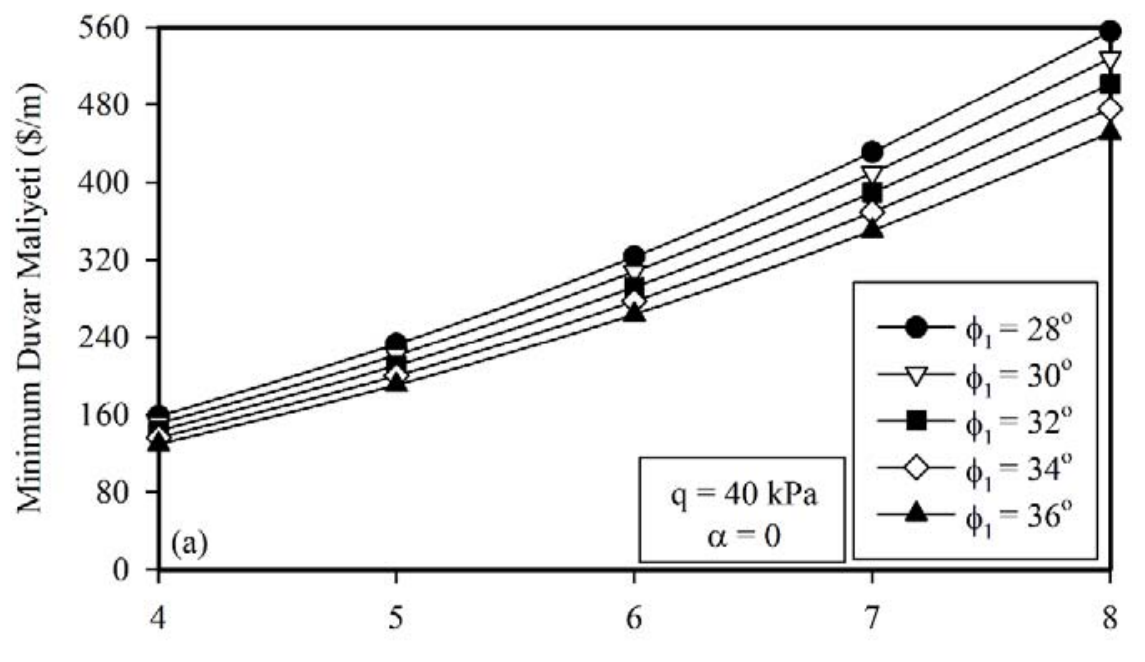

Duvar Yüksekliği, H (m)

Şekil 9. Duvar yüksekliğinin minimum duvar maliyetine etkisi (The effect of the height of wall on the minimum cost of the wall)

ilişkisinin aksine duvar yüksekliği ile minimum duvar maliyeti arasındaki ilişki üstel bir davranış sergilemektedir. Sürşarj yükünün 0 olduğu durumda, duvar yüksekliği 4 m'den 8 m'ye çıktığında, duvarın maliyeti dolgunun içsel sürtünme açısına bağlı olmakla beraber \%244 ile \%292 arasında artmaktadır. Benzer değerlendirme $\mathrm{q}=40 \mathrm{kPa}$ 'lı sürşarj yükü için yapıldığında, maliyet artışının \%249 ile \%251 gibi dar bir aralık içinde kaldığını göstermektedir. Duvar yüksekliğinin 4 m'den 5 m'ye kadar 1 m'lik artırılması durumunda dahi sürşarj yükü ve dolgunun içsel sürtünme açısından bağımsız olarak, duvar minimum maliyetinin \%46 civarında arttı̆̆1 tespit edilmiştir. Duvar yüksekliğinin 5 m'den 6 m'ye, 6 m'den 7 m'ye ve 7 m'den 8 m'ye yükseltilmesi durumlarında ise maliyet artışı sırasıyla ortalama $\% 42, \% 35$ ve $\% 31$ seviyelerine inmektedir. Bu değerlendirme, sağlam zemine oturan betonarme istinat duvarlarının ekonomik tasarımını etkileyen ana faktörün duvar yüksekliği olduğunu göstermektedir.

\section{SIMMELER (SYMBOLS)}

B

$\mathrm{c}_{2}$

CS

$\mathrm{D}_{\mathrm{f}}$

e

$\mathrm{f}_{\mathrm{i}}$

fitness

$f_{\text {cd }}$

$\mathrm{f}_{\mathrm{ctd}}$

$\mathrm{FS}_{\text {(cekme) }}$

$\mathrm{FS}_{\text {(devrilme) }}$

$\mathrm{FS}_{\text {(kayma) }}$

$\mathrm{FS}_{\text {(tasima) }}$

$f_{y d}$

$\mathrm{H}$
: Temel genişliği

: Temel zemininin kohezyonu

: Kolonideki arı sayıs1

: Duvarın önündeki zemin yüksekliği

: Eksantrisite

: Amaç fonksiyonu değeri

: Uygunluk değeri

: Beton için tasarım basınç dayanımı

: Beton için tasarım çekme dayanımı

: Çekmeye karşı güvenlik sayısı

: Devrilmeye karşı güvenlik sayısı

: Kayma yenilmesine karşı güvenlik sayısı

: Taşıma gücü yenilmesine karşı güvenlik sayısı

: Çelik için tasarım akma dayanımı

: Duvar yüksekliği 


$\begin{array}{ll}\mathrm{K}_{\mathrm{a}} & \text { : Rankine aktif toprak basıncı katsayısı } \\ \mathrm{K}_{\mathrm{p}} & \text { : Rankine pasif toprak basıncı katsayısı } \\ \mathrm{M}_{\mathrm{d}} & \text { : Tasarım momenti } \\ \mathrm{M}_{\mathrm{r}} & \text { : Eğilme momenti taşıma gücü kapasitesi } \\ \mathrm{MCN} & \text { : Maksimum döngü sayısı } \\ \mathrm{MR} & : \text { Modifikasyon oranı } \\ \mathrm{q} & : \text { Topuk kısmı üzerindeki sürşarj yükü } \\ \mathrm{q}_{\min } & : \text { Minimum taban basıncı } \\ \mathrm{q}_{\mathrm{max}} & : \text { Maksimum taban basıncı } \\ \mathrm{q}_{\mathrm{ult}} & : \text { Temel zemininin nihai taşıma kapasitesi } \\ \mathrm{V}_{\mathrm{j}}{ }^{\mathrm{i}} & : \text { Yeni yiyecek kaynağ1 } \\ \mathrm{violation}_{\mathrm{i}} & : \text { İhlal değerleri } \\ \mathrm{V}_{\mathrm{d}} & : \text { Tasarım kesme kuvveti } \\ \mathrm{V}_{\mathrm{r}} & : \text { Kesme kapasitesi } \\ \mathrm{x}_{\mathrm{j}} & : \text { Tasarım değişkeni } \\ \mathrm{x}_{\mathrm{j}}{ }^{\mathrm{i}} & : \text { Mevcut yiyecek kaynağı } \\ \mathrm{x}_{\mathrm{j}}{ }^{\min } & : \text { Tasarım değişkeni alt sınırı } \\ \mathrm{x}_{\mathrm{j}}{ }^{\text {max }} & : \text { Tasarım değişkeni üst sınırı } \\ \alpha & : \text { Pasif direnç etki katsayısı } \\ \gamma_{1}, \gamma_{2}, \gamma_{\mathrm{c}} & : \text { Dolgunun, temel zemininin, betonun } \\ \phi_{1} & \text { birim hacim ağırlıkları } \\ \phi_{2} & : \text { Dolgu zemininin içsel sürtünme açısı }\end{array}$

\section{SONUÇLAR (CONCLUSIONS)}

Bu çalışmada, inşaat mühendisliğindeki önemli yapılardan birisi olan betonarme istinat duvarlarının minimum maliyetli tasarımı için yapay arı koloni algoritması kullanılmıştır. Sağlam temel zemini koşullarındaki betonarme istinat duvarlarında, kullanılan dolgu malzemesinin içsel sürtünme açısı, sürşarj yükü, duvar yüksekliği ve pasif dirençlerin dikkate alınma ölçüsünün minimum maliyete etkilerini belirlemek için gerçekleştirilen optimizasyon analizleri sonrasında aşağıdaki bulgulara ulaşılmıştır.

Duvar ön yüzünde yer alan zeminin pasif direnci, duvar maliyetini etkilememektedir. Analiz sonuçları kaymaya karş1 yeterli direncin temel zemininin kayma direnci parametreleri ile sağlanabildiğini ortaya koymaktadır. Duvar arkasında kullanılan dolgu malzemesinin sıkılı̆̆ı, içsel sürtünme açısı ile orantılı olduğu için, dolgu malzemesinin gevşek $\left(\phi_{1}=28^{\circ}\right)$ yerine daha s1k1 $\left(\phi_{1}=36^{\circ}\right)$ yerleştirilmesi duvar maliyetinde \%13,4 ile \%18,9 arasında bir azalma sağlamaktadır. Duvar arkasındaki yükleri modellemek için uygulanan sürşarj yükünün $10 \mathrm{kPa} l 1 \mathrm{k}$ artışı ortalama \%12,7'lik bir maliyet artışına neden olmaktadır. Betonarme istinat duvarlarının ekonomik tasarımını etkileyen ana faktör duvar yüksekliğidir. Duvar yüksekliğinin $1 \mathrm{~m}$ artırılması durumunda, duvar maliyetinde $\% 31$ ila $\% 46$ arasında bir artış oluşmaktadır.

Sonuç olarak, gerçekçi uygulama verilerini içeren geniş bir aralıkta tanimlanan optimizasyon problemlerinin analizleri sonrasında, sağlam zemin tabakalarına oturan betonarme istinat duvarları için dolgunun içsel sürtünme açısı, sürşarj yükü, duvar yüksekliği ve pasif direnç etkileri incelendiğinde, maliyeti etkileyen ana parametrenin duvar yüksekliği olduğu ortaya konulmuştur.

252

\section{KAYNAKLAR (REFERENCES)}

1. Karaboga D., An Idea Based on Honey Bee Swarm Form Numerical Optimization, Technical Report TR06, Erciyes University, Turkey, 2005.

2. Karaboga D., Basturk B., On the Performance of Artificial Bee Colony (ABC) Algorithm, Appl. Soft Comput., 8 (1), 687-697, 2008.

3. Bolaji A.L., Khader A.T., Al-Betar M.A., Awadallah M.A., Artificial Bee Colony Algorithm, Its Variants and Applications: A Survey, J. Theor. Appl. Inf. Technol., 47 (2), 434-459, 2013.

4. Öztürk C., Hancer E., Karaboga D., Automatic Clustering with Global Best Artificial Bee Colony Algorithm, Journal of the Faculty of Engineering and Architecture of Gazi University, 29 (4), 677-687, 2014.

5. Aydin D., Özyön S., Yaşar C., Liao T., Artificial Bee Colony Algorithm with Dynamic Population Size to Combined Economic and Emission Dispatch Problem, Electr. Power Energy Syst., 54, 144-153, 2014.

6. Sonmez M., Artificial Bee Colony Algorithm for Optimization of Truss Structures, Appl. Soft Comput., 11 (2), 2406-2418, 2011.

7. Karaboga D., Okdem S., Ozturk C., Cluster Based Wireless Sensor Network Routing using Artificial Bee Colony Algorithm, Wireless Networks, 18 (7), 847-860, 2012.

8. Saribas A., Erbatur F., Optimization and Sensitivity of Retaining Structures, J. Geotech. Eng., 122 (8), 649656, 1996.

9. Ceranic B., Fryer C., Baines R.W., An Application of Simulated Annealing to the Optimum Design of Reinforced Concrete Retaining Structures, Comput. Struct., 79 (17), 1569-1581, 2001.

10. Babu G.L.S., Basha B.M., Optimum Design of Cantilever Retaining Walls using Target Reliability Approach, Int. J. Geomech., 8 (4), 240-252, 2008.

11. Yepes V., Alcala J., Perea C., Gonzalez-Vidosa F., A Parametric Study of Optimum Earth-Retaining Walls by Simulated Annealing, Eng. Struct., 30, 821-830, 2008.

12. Ahmadi-Nedushan B., Varaee, H., Optimal Design of Reinforced Concrete Retaining Walls Using a Swarm Intelligence Technique, Proceeding of the First International Conference on Soft Computing Technology in Civil, Structural and Environmental Engineering, Civil-Comp Press, Scotland, 2009.

13. Ghazavi M., Bonab S.B., Optimization of Reinforced Concrete Retaining Walls Using Ant Colony Method, ISGSR 2011-Vogt, Schuppener, Straub and Bräu (Eds.), 297-305, 2011.

14. Ghazavi M., Salavati V., Sensitivity Analysis and Design of Reinforced Concrete Cantilever Retaining Walls Using Bacterial Foraging Optimization Algorithm, ISGSR 2011-Vogt, Schuppener, Straub and Bräu (Eds.), 307-314, 2011.

15. Kaveh A., Abadi A.S.M., Harmony Search Based Algorithms for the Optimum Cost Design of Reinforced Concrete Cantilever Retaining Walls, Int. J. Civ. Eng., 9 (1), 1-8, 2011. 
16. Kaveh A., Behnam A.F., Charged System Search Algorithm for the Optimum Cost Design of Reinforced Concrete Cantilever Retaining Walls, Arabian J. Sci. Eng., 38 (3), 563-570, 2013.

17. Kaveh A., Khayatazad M., Optimal Design of Cantilever Retaining Walls Using Ray Optimization Method, Iran. J. Sci. Technol., Transactions of Civil Engineering, $35\left(\mathrm{C1}^{+}\right)$, 261-274, 2014.

18. Camp C.V., Akin A., Design of Retaining Walls Using Big Bang-Big Crunch Optimization, J. Struct. Eng., 138 (3), 438-448, 2012.

19. Akin A., Aydogdu I., Optimum Design of Retaining Walls Using Adaptive Firefly Algorithm, International Civil Engineering and Architecture Symposium for Academicians, Geotechnical Engineering, 57-67, 2014.

20. Sheikholeslami R., Khalili B.G., Sadollah A., Kim J.H., Optimization of Reinforced Concrete Retaining Walls via Hybrid Firefly Algorithm with Upper Bound Strategy, KSCE J. Civ. Eng., 20 (6), 2428-2438, 2016.

21. Pei Y., Xia Y., Design of Reinforced Cantilever Retaining Walls Using Heuristic Optimization Algortihms, Procedia Earth Planet. Sci., 5, 32-36, 2012.

22. Khajehzadeh M., Taha M.R., Eslami M., Efficient Gravitational Search Algorithm for Optimum Design of Retaining Walls, Struct. Eng. Mech., 45 (1), 111-127, 2013.

23. Venkatramaiah C., Geotechnical Engineering, Third Edition, New Age International Publishers, 2006.
24. TS 7994-1990, Zemin Dayanma Yapılar1; Sınıflandırma, Özellikleri ve Projelendirme Esasları, Türk Standardları Enstitüsü, 1990.

25. Das B.M., Principles of Foundation Engineering, Eighth Edition, Cengage Learning, 2016.

26. TS 500-2000, Betonarme Yapıların Tasarım ve Yapım Kuralları, Türk Standardları Enstitüsü, 2000.

27. Karaboga D., Basturk B., Artificial Bee Colony (ABC) Optimization Algorithm for Solving Constrained Optimization Problems, LNCS: Advances in Soft Computing: Foundations of Fuzzy Logic and Soft Computing, Vol: 4529/2007, 789-798, SpringerVerlag, 2007.

28. Karaboga D., Akay B., A Modified Artificial Bee Colony $(\mathrm{ABC})$ Algorithm for Constrained Optimization Problems, Appl. Soft Comput., 11 (3), 3021-3031, 2011.

29. Akay B., Karaboga D., A Modified Artificial Bee Colony Algorithm for Real-Parameter Optimization, Information Sciences, 192, 120-142, 2012.

30. Deb K., An Efficient Constraint Handling Method for Genetic Algorithms, Comput. Methods Appl. Mech. Eng., 186 (2-4), 311-338, 2000.

31. Bowles J.E., Foundation Analysis and Design, Fifth Edition, The McGraw-Hill Com, Inc., New York, 1996.

32. Caltrans, Bridge Design Specifications, Section 5Retaining Walls, California Department of Transportation, Sacramento, California, 2004. 
